\title{
An in vivo stable isotope-based approach for assessment of absorbed amino acids from individual feed ingredients within complete diets
}

\author{
K. A. Estes, ${ }^{*}$ R. R. White, ${ }^{*}$ P. S. Yoder, ${ }^{*}$ T. Pilonero, ${ }^{*}$ H. Schramm, $†$ H. Lapierre, $\ddagger$ and M. D. Hanigan ${ }^{* 1}$ \\ *Department of Dairy Science, and \\ †College of Veterinary Medicine, Virginia Tech, Blacksburg 24061 \\ $\ddagger$ Agriculture and Agri-Food Canada, Sherbrooke, Québec, Canada J1M 0C8
}

\section{ABSTRACT}

Accurate assessment of the nutritional content of feed ingredients is required for precise diet formulation. Characterizing ingredients in terms of absorption and digestibility of individual AA is challenging, and this information often relies on indirect methods. The purpose of this research was to evaluate an in vivo stable isotope-based method of determining plasma entry rates of individual AA from feather meal (FM), blood meal (BM), and a rumen-protected AA (RPMet). Abomasal infusions of unprotected Ile, Leu, Met, and sodium caseinate were used as control treatments to assess technique reliability and accuracy. Isotopic enrichment of plasma $\mathrm{AA}$ in response to a 2-h constant jugular infusion of a mixture of ${ }^{13} \mathrm{C}$ labeled $\mathrm{AA}$ was measured and modeled using a dynamic 4-pool model, which was fitted to each AA by infusion to derive diet entry rates. The resulting entry rate matrix was used to derive plasma entry rates of individual AA from each ingredient by regression. The mean of plasma AA entry for abomasally infused Ile, Leu, and Met was $93.4 \pm$ $7.35 \%$ of that infused, indicating that $6.6 \%$ was used by splanchnic tissues during first pass. The mean of the plasma essential AA entry for abomasally infused casein was $86.7 \pm 4.81 \%$ of that present in the source protein, which represents a mean of $8.7 \%$ first-pass use assuming 95\% digestibility. Individual AA appearances ranged from 86 to $93 \%$ of the source content except Ile, which was $73 \%$. These fractional appearance percentages were similar to those previously reported when using a dietary regression approach. The mean plasma essential AA entry rate for FM was $52.7 \%$ of the AA in the source ingredient, with a range across AA of 48 to $58 \%$. The mean plasma essential AA entry rate for $\mathrm{BM}$ was $47.5 \%$, with a range of 30 to $61 \%$. However, estimated Met availability from the RPMet was lower

Received July 5, 2017.

Accepted March 20, 2018

${ }^{1}$ Corresponding author: mhanigan@vt.edu
$(9.9 \%)$ than expected (42\%). This may be due to the relatively larger errors of measurement for Met entry rates and a small change in RPMet inclusion. Assuming that rumen-undegraded protein absorption is reflective of aggregated essential AA entry rates after correction for first-pass use, 52.6 and $61.2 \%$ of dietary FM and BM CP was absorbed from the intestine, respectively, which yielded an estimated intestinal digestibility of 70 and $66 \%$, respectively. This method appears to provide an accurate and precise in vivo assessment of individual AA plasma entry rates that can be used to better characterize individual feed ingredients in ruminants. Such information will result in more robust economic assessments of feeds and increased precision of diet formulation.

Key words: amino acid, digestibility, absorption, ruminant, stable isotope

\section{INTRODUCTION}

Lactating dairy cattle in North America typically capture $25 \%$ of consumed dietary $\mathrm{N}$ in milk and tissue (Hristov et al., 2004). Accurate predictions of the intestinal supply of AA from dietary ingredients escaping ruminal degradation and from microbial protein are necessary to more precisely match the dietary supply of individual AA to requirements. Improving models used to balance dairy rations for AA will optimize milk protein yield and increase $\mathrm{N}$ efficiency (Khezri et al., 2011). Several in vitro, in situ, and in vivo methods of assessing protein and AA supplies to the animal have been developed; however, they all have limitations.

Quantification of protein and AA availability of a single feed ingredient requires knowledge of its rumen disappearance and intestinal digestibility. In vitro methods have been demonstrated to have utility in ranking feed ingredients relative to protein availability (Calsamiglia and Stern, 1995; Stern et al., 1997; Gargallo et al., 2006; Ross et al., 2013), and the rankings are correlated with in vivo performance (Noftsger and St-Pierre, 2003; Gutierrez-Botero et al., 2014). However, there is considerable variation within and across 
laboratories (Estes, 2016), and the methods do not generate absolute values that can be used directly in a model. Some of this variation derives from the enzymes used to replicate digestion and the extent to which they duplicate in vivo digestion (Stern et al., 1997). Rumen degradation can be determined using batch cultures, but ammonia accumulation in batch cultures can also be problematic (Colombini et al., 2011), causing rates of degradation to decline over the incubation time (Paz et al., 2014). Intestinal digestibility has been estimated in vitro using 3-step procedures (Calsamiglia and Stern, 1995), but the original method lacks the ability to determine individual AA digestibility due to termination of incubations with trichloroacetic acid pulling down contaminating enzymatic protein (Ross et al., 2013). The ruminal in situ methods require an estimate of the rate of passage of particulate matter, which is problematic, and can overestimate ruminal degradation due to the assumption that all solubilized $\mathrm{N}$ is degraded (White et al., 2017). Assessment of postruminal digestibility using an in situ approach with sample collection in the feces may also overestimate digestibility due to large intestinal fermentation and residence times that often exceed normal intestinal residence times (e.g., 42 h; Arriola Apelo et al., 2014a).

In vivo efforts to measure absorption are technically difficult because of the need to surgically insert cannulas into the duodenum and ileum (Titgemeyer et al., 1989) or place a catheter into one artery and mesenteric or portal vein (MacRae et al., 1997a,b). These techniques, however, can hardly be applied to a single feed ingredient. Alternatively, cecectomized roosters have been used to address hindgut fermentative loss, allowing assessments of fed ingredients (Boucher et al., 2009). Apparent total-tract digestibilities can also be derived by regression from dietary substitution (MacRae et al., 1997b). However, there are often limits to how much of an ingredient an animal will voluntarily consume, which magnifies errors of measurement. Additional work is required to account for microbial AA metabolism and remodeling in the rumen and hindgut (Waltz et al., 1989).

Determination of AA availability via plasma concentration responses in steady state or after an abomasal pulse dose of the ingredient of interest compared with a dose of the unprotected AA has been used to assess rumen-protected (RP) Met and RPLys (Graulet et al., 2005; Whitehouse et al., 2016). A concern with the latter method is that the large dose may induce AA catabolism (Harper, 1965). If the dose of the reference $\mathrm{AA}$ is similar to that of the ingredient, the concern is minimized assuming both will elicit the same catabolic response. Another issue is that the ingredient of inter- est is not fed and does not undergo handling and other feed environment forces that may affect performance.

An isotope-based approach that avoids the need for extensive surgical alteration of the animals has been tested by Borucki Castro et al. (2008) and Maxin et al. (2013). The method is based on assessment of rates of labeled AA clearance from the plasma pool after a pulse dose into the jugular vein. Because of the rapid turnover $(\mathbf{T} / \mathbf{O})$ of plasma $\mathrm{AA}$, enrichment of the traced AA returned to background in $30 \mathrm{~min}$, which resulted in a very short sampling window subject to short-term variation in absorption rates. When used to assess recovery of abomasally infused Lys and Met, recoveries of 95 and $96 \%$ (Maxin et al., 2013), respectively, and $100 \%$ for Lys (Borucki Castro et al., 2008) were observed, indicating that the method generates reliable estimates.

The in vivo method of Borucki Castro et al. (2008) appears promising. However, further development is needed to extend it to other AA and to address the challenges of the relatively short sampling window. Our hypothesis was that a constant jugular infusion of a mixture of isotopically labeled AA over a longer time frame would expand the window of observation and the number of AA being observed, yielding more complete and precise information. The objectives were (1) to expand the number of AA considered, (2) to develop a dynamic model to interpret non-steady state data, (3) to evaluate the accuracy and precision of the revised method, and (4) to assess the absorbed AA supplied by soybean meal (SBM), feather meal (FM), blood meal (BM), a RPMet prototype, abomasally infused sodium caseinate (control treatment), or an abomasally infused mixture of Met, Ile, and Leu (control treatment). The $\mathrm{BM}$ and FM were specifically chosen due to concern in the industry regarding their true AA digestibilities in ruminants.

\section{MATERIALS AND METHODS}

\section{Experiment 1: Isotope Experiment}

Animals, Treatments, and Diet Compositions. All animal procedures were approved by the Virginia Tech Animal Care and Use Committee. Six Holstein steers (1 yr of age; $340 \pm 34 \mathrm{~kg}$ of $\mathrm{BW}$ ) were randomly assigned to 1 of 6 treatment sequences in a 6 $\times 6$ Latin square design with 10 -d periods. Diets were formulated to meet or exceed all NRC (2001) recommendations for a replacement heifer weighing $317 \mathrm{~kg}$, gaining $1 \mathrm{~kg} / \mathrm{d}$, and consuming $7.4 \mathrm{~kg}$ of $\mathrm{DM} / \mathrm{d}$. Diets were formulated to exceed $20 \% \mathrm{CP}$ to ensure that there were minimal differences in rates of microbial protein 
Table 1. Ingredient and formulated nutrient composition of the experiment 1 treatment diets (\% of DM)

\begin{tabular}{|c|c|c|c|c|c|c|}
\hline \multirow[b]{2}{*}{ Item } & \multicolumn{6}{|c|}{ Treatment $^{1}$} \\
\hline & $\mathrm{BD}$ & Casein & EAA & $\mathrm{BM}$ & FM & RPMet \\
\hline \multicolumn{7}{|l|}{ Ingredient } \\
\hline Grass hay, mature & 34.61 & 34.65 & 34.60 & 34.59 & 34.67 & 34.62 \\
\hline Corn silage, mature & 34.62 & 34.63 & 34.63 & 34.62 & 34.67 & 34.67 \\
\hline Soybean meal solvent $48 \% \mathrm{CP}$ & 29.71 & 28.21 & 27.69 & 27.79 & 28.22 & 29.31 \\
\hline EAA & - & - & 2.01 & - & - & - \\
\hline Blood meal & - & - & - & 1.94 & - & - \\
\hline Feather meal & - & - & - & - & 1.39 & - \\
\hline Rumen-protected Met & - & - & - & - & - & 0.31 \\
\hline Casein & - & 1.51 & - & - & - & - \\
\hline Vitamin E premix & 0.07 & 0.07 & 0.07 & 0.07 & 0.07 & 0.07 \\
\hline Vitamin and mineral premix & 0.94 & 0.94 & 0.94 & 0.94 & 0.94 & 0.94 \\
\hline Salt & 0.05 & - & 0.05 & 0.05 & 0.05 & 0.05 \\
\hline \multicolumn{7}{|l|}{ Formulated nutrient ${ }^{2}$} \\
\hline $\mathrm{CP}(\%)$ & 20.6 & 21.3 & 21.6 & 21.5 & 21.0 & 20.7 \\
\hline \multicolumn{7}{|l|}{$\operatorname{RDP}(\mathrm{g} / \mathrm{d})$} \\
\hline Required & 752 & 753 & 736 & 749 & 752 & 753 \\
\hline Supplied & 950 & 916 & 905 & 941 & 948 & 945 \\
\hline \multicolumn{7}{|l|}{$\mathrm{ME}(\mathrm{Mcal} / \mathrm{d})$} \\
\hline Required & 9.7 & 9.7 & 9.7 & 9.7 & 9.7 & 9.7 \\
\hline Supplied & 19.1 & 19.2 & 18.6 & 19.0 & 19.1 & 19.1 \\
\hline $\operatorname{NDF}(\%)$ & 36.3 & 36.2 & 36.1 & 36.1 & 36.2 & 36.3 \\
\hline $\operatorname{ADF}(\%)$ & 22.8 & 22.8 & 22.7 & 22.7 & 22.8 & 22.3 \\
\hline $\mathrm{NE}_{\mathrm{G}}(\mathrm{Mcal} / \mathrm{kg}$ of $\mathrm{DM})$ & 1.05 & 1.06 & 1.02 & 1.05 & 1.05 & 1.06 \\
\hline Ether extract $(\%)$ & 2.9 & 2.8 & 2.8 & 2.8 & 3.0 & 2.9 \\
\hline
\end{tabular}

synthesis or rates of AA use for body protein synthesis. Diets were constructed from a mixture of corn silage, grass hay, SBM, salt, vitamins, and minerals (Table 1). Blood meal, FM, an RPMet prototype, abomasally infused sodium caseinate (casein treatment), and an abomasally infused mixture of Met, Ile, and Leu (EAA treatment) were substituted for SBM in the base diet (BD) on a DM basis. Feather and BM inclusion rates were set based on the maximal tolerable level of inclusion as determined by sustained depressions of DMI in a pilot trial using 2 of the animals (data not shown). The predicted duodenal flows of AA for each diet at the mean observed DMI for each treatment are presented in Table 2.

The experimental timeline is presented in Figure 1. On d 1 to 5 of each period, steers were fed their respective treatment diets ad libitum except for those on the casein and EAA treatments, which were fed the $\mathrm{BD}$ diet. On d 6 of each period, steers were moved to metabolism stalls and fed every $6 \mathrm{~h}$. An infusion line constructed from tygon tubing was inserted into the abomasum of the steer on the casein treatment via the rumen cannula and omasal orifice (Spires et al., 1975), and a sodium caseinate infusion was initiated at 1000 h. The infused sodium caseinate $(1.51 \%$ of the observed DMI on the previous $2 \mathrm{~d}$ ) was dissolved in $6 \mathrm{~L}$ of water and delivered at a rate of $250 \mathrm{~mL} / \mathrm{h}$ using clinical infusion pumps (LifeCare 5000, Abbott Laboratories, North Chicago, IL). At the same time, the diet was shifted from BD to the casein diet.

On d 9, feeding frequency increased to every $2 \mathrm{~h}$, and feed offered was reduced to $95 \%$ of the ad libitum DMI observed at d 5 to 8 to help ensure that each meal was consumed when offered. This was done to minimize variation in AA absorption. An infusion line was placed into the abomasum of the steer receiving the EAA diet as above, an infusion of L-Ile, L-Leu, and DL-Met (0.64, 1.13 , and $0.22 \%$, respectively, of the observed DMI from the previous $2 \mathrm{~d}$ dissolved in $6 \mathrm{~L}$ of water and delivered at $250 \mathrm{~mL} / \mathrm{h}$ ) was started at $1000 \mathrm{~h}$, and the diet was shifted from BD to the EAA diet.

Diet, ingredient, and orts samples were collected daily from d 7 to 10 between 0700 and $0800 \mathrm{~h}$, composited by period, and dried at $55^{\circ} \mathrm{C}$. Spot collection of feces $(400$ g) occurred from d 7 to 10 starting at $0600 \mathrm{~h}$ on $\mathrm{d} 7$ and rotating forward $2 \mathrm{~h}$ on the second day of collection and $4 \mathrm{~h}$ on the third day of collection (see Figure 1).

Isotope Infusion and Blood Sampling. On d 8 of each period, steers were fitted with 2 jugular catheters: a $90 \mathrm{~cm} \times 2.03 \mathrm{~mm}$ i.d. microrenathane (Braintree Scientific Inc., Braintree, MA) catheter for isotope infusions (45 cm inserted into the jugular) and a 13 $\mathrm{cm} \times 14 \mathrm{~g}$ (Jorvet, Loveland, CO) catheter for blood sampling. The infusion catheter tip was approximately 


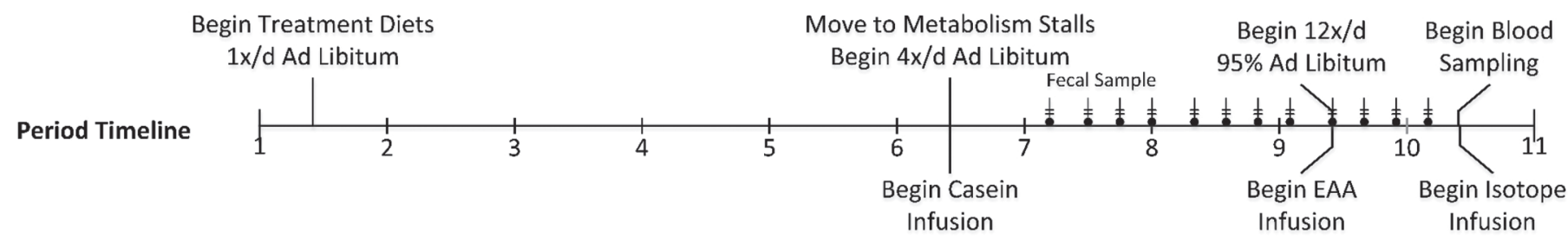

$$
\begin{aligned}
& \neq=\text { fecal sampling } \\
& \downarrow \\
& \downarrow=\text { blood sampling }
\end{aligned}
$$

Day 10 Timeline

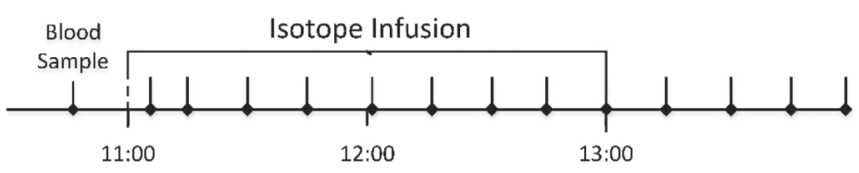

Figure 1. A timeline for each period in experiment 1. Units for the period timeline are days, and units for the Day 10 timeline are hour of the day.

$40 \mathrm{~cm}$ cauda (downstream) from the tip of the blood sampling catheter to ensure that sampled blood transited through the circulatory system before collection. Catheter placement alternated sides in successive periods.

Isotope infusions and blood collections were conducted on d 10 (see Figure 1). Prior to each infusion, $0.5 \mathrm{~g}$ of ${ }^{13} \mathrm{C}$ labeled AA derived from algae $\left(\mathrm{U}_{-}{ }^{13} \mathrm{C}\right.$, $97-99 \%$ enriched), $12.9 \mathrm{mg}$ of ${ }^{13} \mathrm{C}$ labeled L-His-HCl$\mathrm{H}_{2} \mathrm{O}$ (ring- $2{ }^{13} \mathrm{C}$, 99\% enriched), and $10 \mathrm{mg}$ of ${ }^{13} \mathrm{C} \mathrm{L}$ Met (methyl $-{ }^{13} \mathrm{C}_{3}, 99 \%$ enriched; all from Cambridge Isotope Laboratories, Andover, MA) were dissolved in
$250 \mathrm{~mL}$ of saline and sterile filtered $(0.22-\mu \mathrm{m}$ filter, Sterivex, Millipore, Billerica, MA). The ${ }^{13} \mathrm{C}$ L-His and ${ }^{13} \mathrm{C}$ L-Met were added to the infusate as a supplement to the hydrolyzed algae, which was low in both AA. Initial calculations and a pilot trial indicated that additional label may be required to achieve adequate blood enrichment to reliably determine entry rates. Although the kinetics of the added ${ }^{13} \mathrm{C}$ Met may differ from those of the algal-derived Met, it was added at a constant ratio to algae across all infusions and thus would not alter interpretation of the data. The solution was infused into the jugular vein at a constant rate of $2 \mathrm{~mL} / \mathrm{min}$

\begin{tabular}{|c|c|c|c|c|c|c|}
\hline \multirow[b]{2}{*}{ Item } & \multicolumn{6}{|c|}{ Treatment $^{1}$} \\
\hline & $\mathrm{BD}$ & Casein & EAA & $\mathrm{BM}$ & FM & RPMet $^{2}$ \\
\hline \multicolumn{7}{|c|}{ Predicted duodenal digestible AA flow (g/d) } \\
\hline Histidine & 23 & 28 & 24 & 27 & 24 & 22 \\
\hline Isoleucine & 51 & 51 & 88 & 53 & 54 & 48 \\
\hline Leucine & 91 & 101 & 160 & 101 & 97 & 84 \\
\hline Lysine & 67 & 73 & 71 & 72 & 70 & 63 \\
\hline Methionine & 18 & 19 & 31 & 19 & 19 & 25 \\
\hline Phenylalanine & 54 & 59 & 60 & 59 & 57 & 50 \\
\hline Threonine & 49 & 52 & 51 & 53 & 53 & 46 \\
\hline Valine & 56 & 62 & 61 & 62 & 60 & 52 \\
\hline \multicolumn{7}{|c|}{ Predicted duodenal AA flow (\% MP) } \\
\hline Histidine & 2.25 & 2.52 & 2.03 & 2.40 & 2.20 & 2.24 \\
\hline Isoleucine & 4.90 & 4.63 & 7.47 & 4.72 & 4.85 & 4.92 \\
\hline Leucine & 8.73 & 9.12 & 13.61 & 9.02 & 8.74 & 8.68 \\
\hline Lysine & 6.43 & 6.56 & 6.00 & 6.44 & 6.27 & 6.53 \\
\hline Methionine & 1.73 & 1.69 & 2.63 & 1.70 & 1.69 & 2.58 \\
\hline Phenylalanine & 5.17 & 5.30 & 5.12 & 5.25 & 5.14 & 5.20 \\
\hline Threonine & 4.74 & 4.72 & 4.34 & 4.72 & 4.73 & 4.77 \\
\hline Valine & 5.40 & 5.63 & 5.21 & 5.33 & 5.41 & 5.43 \\
\hline
\end{tabular}

Table 2. Digestible AA flow at observed DMI predicted by the NRC (2001) model for experiment 1

${ }^{1} \mathrm{BD}=$ base diet; Casein = abomasal infusion of sodium caseinate; $\mathrm{EAA}=$ abomasal infusion of Met, Leu, and Ile; $\mathrm{BM}=$ blood meal; $\mathrm{FM}=$ feather meal; RPMet $=$ rumen-protected Met.

${ }^{2}$ Used NRC (2001) settings of $\mathrm{CP}=79.9 \%$, CP A fraction $=45 \%, \mathrm{CP}$ B fraction $=0, \mathrm{CP}$ C fraction $=55 \%$, and RUP digestibility $=100 \%$ to simulate the observed intestinal availability determined from the abomasal pulse dose. 
over $2 \mathrm{~h}$ starting at $1100 \mathrm{~h}$ and ending at $1300 \mathrm{~h}$ using clinical infusion pumps as above.

Blood was sampled at $-15,5,15,30,45,60,75,90$, $105,120,135,150,165$, and $180 \mathrm{~min}$ relative to the start of the infusion and stored on ice $(\leq 5 \mathrm{~h}$ from the first blood sample). This was followed by plasma preparation by centrifugation $(1,663 \times g$ for $12 \mathrm{~min})$ and storage in polypropylene tubes at $-20^{\circ} \mathrm{C}$ until further analysis.

Plasma samples were deproteinized using sulfosalicylic acid (50\% vol/vol) and centrifugation, desalted by ion exchange (BioRad Resin AG 50-X*, 100-200 mesh; Rio-Rad, Hercules, CA), and eluted using ammonium hydroxide $(2 \mathrm{~N})$ into silanized glassware as described by Calder et al. (1999). Desalted samples were freeze dried, resolubilized in $0.1 \mathrm{~N} \mathrm{HCl}$, and derivatized as described by Hušek (1991), and a subsample of the organic phase was separated by GC and assessed for isotopic enrichment of the $\mathrm{CO}_{2}$ arising from eluted AA using an isotope ratio mass spectrometer coupled to a GC by a combustion oven (Thermo Scientific, Waltham, MA; Sessions, 2006). The enrichment of all EAA except Arg can be determined using this method; Arg is destroyed during derivatization (Hušek, 1991). However, the detection of His was very difficult due to recovery problems associated with retention on metal and glass machine parts and thus was not reported in this work. All data were expressed as tracer/tracee ratios $\left({ }^{13} \mathrm{C} /{ }^{12} \mathrm{C}\right)$.

Isotope Model Derivation. A 4-pool, dynamic system of differential equations and accompanying state variables was constructed and used to derive plasma AA entry rates from observed isotopic enrichment data for each AA. A representation of the model is presented in Figure 2. The model was designed to accommodate constant, pulse-chase, and pulse-dose infusions, although it was only used for simulations of constant infusions herein. The model was coded in ACSLX (version 3.1.4.2, Aegis Technologies, Huntsville, AL). For presentation of the model, $\mathrm{Q}$ represents a state variable (mmol), F represents fluxes $(\mathrm{mmol} / \mathrm{min}), \mathrm{C}$ represents concentrations $(\mathrm{m} M)$, and $\mathrm{V}$ represents volume $(\mathrm{L})$.

The 4 state variables were (1) total AA (labeled plus unlabeled) in a fast T/O pool (QAA $\mathbf{A}_{\text {Fast }}$ ), (2) isotopically labeled AA in a fast T/O pool (QAA ${ }_{\text {Fast }}$ ), (3) total AA (labeled plus unlabeled) in a slow $\mathrm{T} / \mathrm{O}$ pool $\left(\mathbf{Q A A}_{\text {Slow }}\right)$, and (4) isotopically labeled AA in a slow T/O pool (QAA* ${ }_{\text {slow }}$ ). Turnover time is defined as the pool size divided by the rate of entry, which dictates the kinetics of the system. A pool with a large $\mathrm{T} / \mathrm{O}$ time is turning over slowly, and the reverse is true for a short $\mathrm{T} / \mathrm{O}$ time. Herein, any reference to a slow $\mathrm{T} / \mathrm{O}$ pool indicates a long $\mathrm{T} / \mathrm{O}$ time and vice versa. Attempts to fit an additional set of slow $\mathrm{T} / \mathrm{O}$ pools as achieved by Hanigan et al. (2009) resulted in an unidentifiable model, indicating that the data were inadequate to derive the additional parameters. We chose to represent the primary pools as total AA because no manipulation of the pool size is required to represent the kinetics. Because stable isotope infusions can - and often do-alter the size of the pool, one must consider the total pool size when predicting flux rates that are dependent on concentration or pool size. If the model is represented as labeled and unlabeled pools, the pools would have to be summed each iteration to determine the total

\section{A) Total Model}

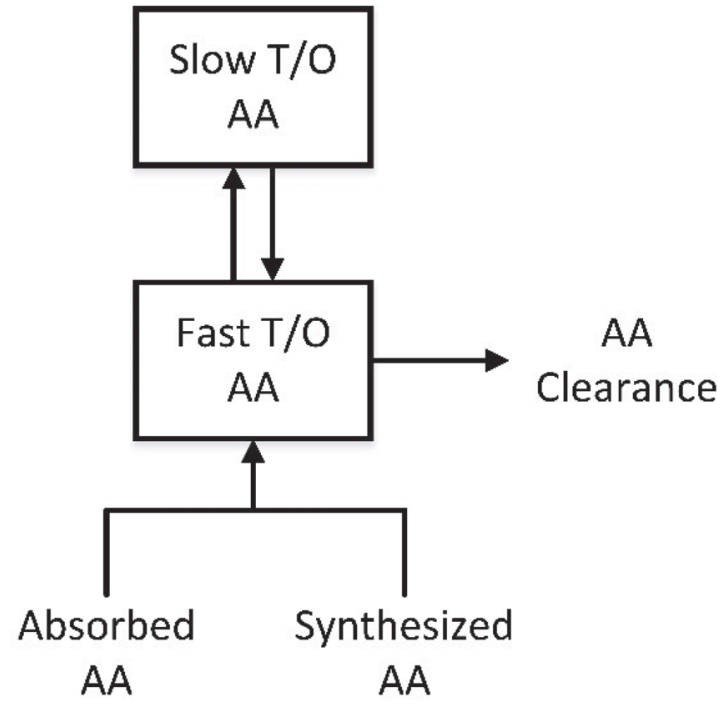

\section{B) Labelled Model}

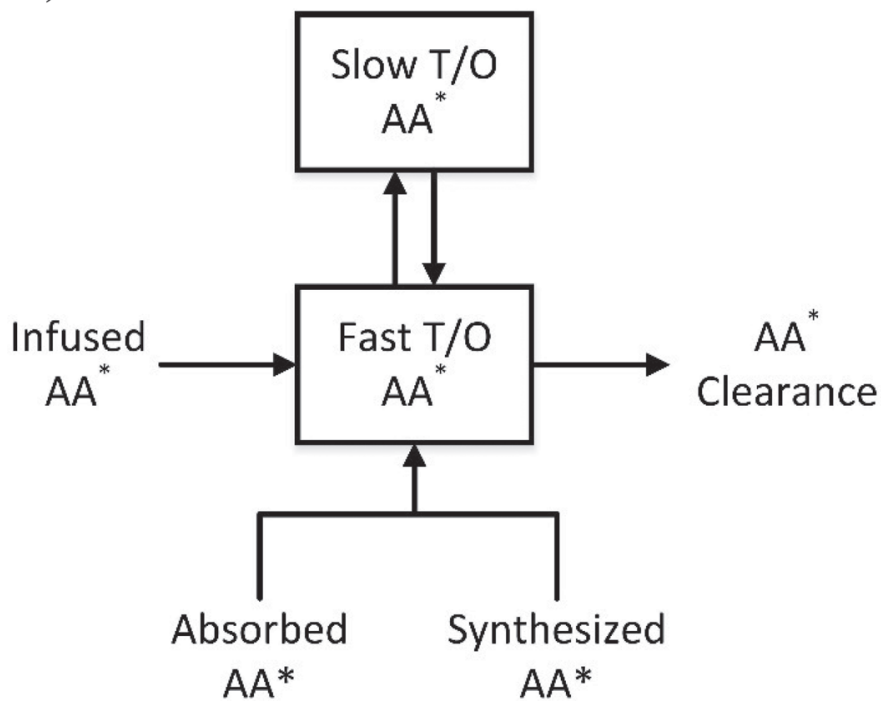

Figure 2. A schematic representation of the model used to derive AA entry rates. The model was fit to plasma AA enrichment data for each $\mathrm{AA} . \mathrm{T} / \mathrm{O}=$ turnover. Asterisk denotes ${ }^{13} \mathrm{C}$ labeling. 


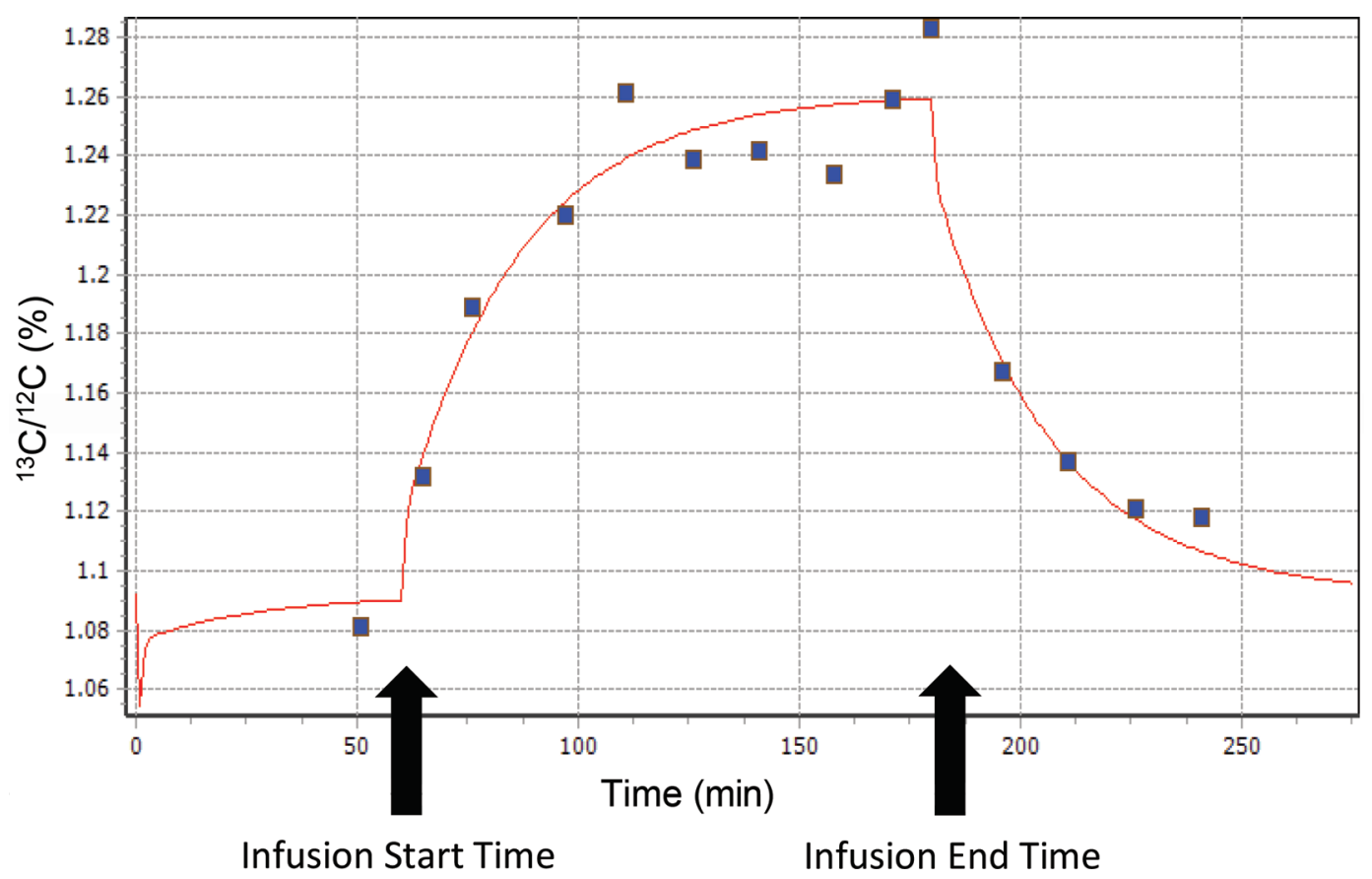

Figure 3. Predicted and observed Ile isotopic ratios versus infusion time for 1 infusion in experiment 1 . Color version available online.

pool size so a flux rate could be calculated. The additional advantage of representing the primary pools in total form is they have the same units as the measured concentrations (i.e., AA concentration measurements do not discriminate among isotopes). However, it is important to note that either approach yields valid and identical results provided the model is coded correctly and matched to the data.

The fast $\mathrm{T} / \mathrm{O}$ pools were assumed to represent primarily blood, interstitial, and cytoplasmic free AA space; however, they also likely include some contribution from rapid $\mathrm{T} / \mathrm{O}$ proteins. For example, any proteins with half-lives of $30 \mathrm{~min}$ or less would exchange substantial AA with the fast pool in the first $10 \mathrm{~min}$ and thus would be difficult to distinguish from the free AA pool and tend to mathematically segregate with the fast T/O AA pools in a 2-pool scheme (Hanigan et al., 2009). Some label was also likely resident in some recoverable breakdown products such as keto acids, homocysteine, saccharopine, and so on that would rapidly equilibrate with the blood pool.

The slow $\mathrm{T} / \mathrm{O}$ pools would be expected to represent only protein-bound AA, and the large size of this pool confers much of the delay in achieving steady-state enrichment in the system. However, a significant proportion of this pool turns over very slowly, and it is difficult to derive an estimate for that proportion during a 2-h infusion as used herein (Hanigan et al., 2009). Thus, the apparent size and rate of $\mathrm{T} / \mathrm{O}$ of the slow $\mathrm{T} / \mathrm{O}$ pool derived from fits to the temporal blood enrichment data will be substantially less than the total body protein pool resulting in an underestimate of the true plateau and thus an overestimate of the absolute entry rates. A longer infusion time should allow derivation of at least one more set of pools which would reduce this error, but it would still be a large simplification of the tremendous heterogeneity in $\mathrm{T} / \mathrm{O}$ rates for the myriad of AA-containing pools in the body. However, as noted above, the complexity of the model was the maximum that could be supported given the data and the model appeared to describe the observations in an unbiased manner, underscoring the need for a longer infusion to disclose the remaining effects (Figure 3).

The underestimate of plateau (steady-state) enrichment and overestimate of entry rates was also observed by Borucki Castro et al. (2008). This does not pose a problem in deriving true entry rates for each diet and ingredient provided that rates of protein synthesis are similar across treatments. Any bias in the protein synthesis estimates will be present in BD entry rates and thus removed by difference from all of the other treatments as discussed by Borucki Castro et al. (2008), leaving only $\mathrm{BD}$ with biased entry rate estimates.

Total AA Pools. The differential (d) for $\mathrm{QAA}_{i \text { Fast }}$ with respect to time $t\left(\mathrm{dQAA}_{i \text { Fast }} / \mathrm{d} t, \mathrm{mmol} / \mathrm{min}\right)$ for the $i$ th AA $(i=$ Ile, Leu, Lys, Met, Phe, Thr, Val, Ala, Asp, Gly, Pro, and Tyr) was represented as the difference between AA entry and exit rates: 


$$
\begin{aligned}
& \mathrm{dQAA}_{i \text { Fast }} / \mathrm{d} t=\mathrm{FAA}_{i \text { Entry }}+\mathrm{FAA}_{i \text { Infused }} \\
&+\mathrm{FAA}_{i \text { SlowFast }}-\mathrm{FAA}_{i \text { Clearance }}-\mathrm{FAA}_{i \text { FastSlow }},
\end{aligned}
$$

where FAA $_{i \text { Entry }}$ was a constant representing absorbed plus synthesized AA. The variable $\mathrm{F}_{i \text { Infused }}$ represented infused AA and was defined as a fixed rate that was 0 outside of the period of the infusion and set to the observed infusion rate $\left(\mathrm{F}_{i}\right.$ ObsInfused $)$ during the infusion:

$$
\mathrm{F}_{i \text { Infused }}=\left\{\begin{array}{cc}
t_{\text {InfStart }}<t<t_{\text {InfStop }}, & \mathrm{F}_{i} \text { ObsInfused } \\
t<t_{\text {InfStart }} \text { or } t>t_{\text {InfStop }}, & 0
\end{array}\right.
$$

where $t_{\text {InfStart }}$ and $t_{\text {InfStop }}$ were the observed start and stop times for the isotope infusion. $\mathrm{FAA}_{i}$ Clearance represented clearance from the fast $\mathrm{T} / \mathrm{O}$ pool (oxidation or conversion to other compounds) and was defined as a mass action function of $\mathrm{QAA}_{i \text { Fast: }}$ :

$$
\mathrm{FAA}_{i \text { Clearance }}=\mathrm{KAA}_{i \text { Clearance }} \times \mathrm{QAA}_{i \text { Fast }},
$$

where $\mathrm{KAA}_{i}$ Clearance $\left(\min ^{-1}\right)$ was the mass action loss constant. The variable $\mathrm{FAA}_{i \text { FastSlow }}$ represented transfer of AA from the fast T/O pool to the slow pool, and $\mathrm{FAA}_{i \text { SlowFast }}$ represented the reverse. Both were defined as mass action functions of the precursor pools:

$$
\begin{aligned}
\mathrm{FAA}_{i \text { FastSlow }} & =\mathrm{KAA}_{i \text { FastSlow }} \times \mathrm{QAA}_{i \text { Fast }} \\
\mathrm{FAA}_{i \text { SlowFast }} & =\mathrm{KAA}_{i \text { SlowFast }} \times \mathrm{QAA}_{i \text { Slow }},
\end{aligned}
$$

where $\mathrm{KAA}_{i \text { FastSlow }}$ and $\mathrm{KAA}_{i}$ SlowFast were the mass action constants $\left(\mathrm{min}^{-1}\right)$. Expressing these protein $\mathrm{T} / \mathrm{O}$ fluxes as mass action functions provides biological measures of the fractional synthesis and degradation rates. In large part, FAA $_{i \text { FastSlow }}$ would represent protein synthesis from the free AA pool and $\mathrm{FAA}_{i}$ SlowFast protein degradation, but as noted above, it is likely that some very fast $\mathrm{T} / \mathrm{O}$ protein and interconversion among recoverable degradation products are represented in the fast pool, and thus these fluxes likely do not represent all of the protein synthesis and breakdown occurring in the body.

The initial size (i) of $\mathrm{QAA}_{i}$ Fast was calculated from observed plasma AA concentrations $(\mathrm{mmol} / \mathrm{L})$ and pool volume $\left(\mathrm{VAA}_{i \text { Fast }} ; \mathrm{L}\right)$ as

$$
\mathrm{iQAA}_{i \text { Fast }}=\mathrm{CAA}_{i \text { Fast }} \times \mathrm{VAA}_{i \text { Fast }} .
$$

The total fast AA pool size at any point in time was calculated by numerical integration of $\mathrm{dQAA}_{i \text { Fast }} / \mathrm{d} t$

$$
\mathrm{QAA}_{i \text { Fast }}=\int \frac{\mathrm{dQAA}_{i \text { Fast }}}{\mathrm{d} t}+\mathrm{iQAA}_{i \text { Fast }}
$$

using a second-order Runge-Kutta-Fehlberg variablestep algorithm with a maximum step size of $0.1 \mathrm{~min}$; iQAA $_{i \text { Fast }}$ was the initial pool size.

The differential for $\mathrm{QAA}_{i}$ slow with respect to time $\left(\mathrm{dQAA}_{i \text { Slow }} / \mathrm{d} t\right)$ is defined as

$$
\mathrm{dQAA}_{i \text { Slow }} / \mathrm{d} t=\mathrm{FAA}_{i \text { SlowFast }}+\mathrm{FAA}_{i \text { SlowFast }}
$$

and the pool size at any point in time is defined as

$$
\mathrm{QAA}_{i \text { Slow }}=\int \frac{\mathrm{dQAA}_{i \text { Slow }}}{\mathrm{d} t}+\mathrm{iQAA}_{i \text { Slow }},
$$

with integration conducted numerically as above. However, any change in the size of the total slow T/O AA pool would be negligible over the course of even an 8-h infusion; thus, the user may choose to set the differential to $0 . \mathrm{iQAA}_{i \text { Slow }}(\mathrm{mmol})$ was defined as

$$
\begin{aligned}
& \mathrm{iQAA}_{i \text { Slow }}=\mathrm{BW} \times 1,000 \times \mathrm{CProt}_{\mathrm{BW}} \times \mathrm{KBW}_{\mathrm{AA}} \\
& \times \mathrm{CAA}_{i \text { Prot }} / \mathrm{MW}_{i \mathrm{AA}} \times 1,000,
\end{aligned}
$$

where BW was expressed in kilograms, CProt $_{\mathrm{BW}}$ represented the fractional proportion of $\mathrm{BW}$ in protein, $\mathrm{KBW}_{\mathrm{AA}}$ was a fractionation coefficient defining the proportion $(\mathrm{g} / \mathrm{g})$ of body protein resident in $\mathrm{QAA}_{i \text { Slow }}$, $\mathrm{CAA}_{i}$ Prot represented the concentration of each AA in body protein $(\mathrm{g} / \mathrm{g})$, and $\mathrm{MW}_{i \mathrm{AA}}$ represented the molecular weight of each AA $(\mathrm{g} / \mathrm{mol})$.

Isotopically Labeled Pools. Isotopically labeled variables follow the same form as the total AA model and are denoted by an asterisk. The differential equation describing changes in the isotopically labeled fast $\mathrm{T} / \mathrm{O}$ AA pool with respect to time $\left(\mathrm{dQAA}^{*}{ }_{i \text { Fast }} / \mathrm{d} t\right)$ was

$$
\begin{array}{r}
\mathrm{dQAA}^{*}{ }_{i \text { Fast }} / \mathrm{d} t=\mathrm{FAA}^{*}{ }_{i \text { Entry }}+\mathrm{FAA}^{*}{ }_{i \text { Infused }} \\
+\mathrm{FAA}^{*}{ }_{i \text { SlowFast }}-\mathrm{FAA}{ }_{i \text { Clearance }}-\mathrm{FAA}^{*}{ }_{i \text { FastSlow }},
\end{array}
$$

where the isotope fluxes were calculated as a product of the total fluxes and isotopic enrichment (e) of the precursor pools:

$$
\begin{aligned}
& \text { FAA }_{i \text { Entry }}=\text { FAA }_{i \text { Entry }} \times \mathrm{eAA}_{i \text { Background }} \\
& \mathrm{FAA}^{*}{ }_{\text {Infused }}=\mathrm{FAA}_{i \text { Infused }} \times \mathrm{eAA}_{i \text { Infused }} \\
& \text { FAA }^{*}{ }_{\text {Clearance }}=\mathrm{FAA}_{i \text { Clearance }} \times \mathrm{eAA}_{i \text { Fast }} \\
& \mathrm{FAA}^{*}{ }_{i \text { FastSlow }}=\mathrm{FAA}_{i \text { FastSlow }} \times \mathrm{eAA}_{i \text { Fast }} \\
& \mathrm{FAA}^{*}{ }_{i \text { SlowFast }}=\mathrm{FAA}_{i \text { SlowFast }} \times \mathrm{eAA}_{i \text { Slow }}
\end{aligned}
$$


The labeled infusion rate was calculated as the product of the mass, AA composition, and enrichment of the algae plus the mass and enrichment of the added Met and His corrected for the proportion of carbons labeled. The size of the labeled fast T/O AA pool was calculated by numerical integration of $\mathrm{dQAA}^{*}{ }_{i \text { Fast }} / \mathrm{d} t$ :

$$
\mathrm{QAA}_{i \text { Fast }}=\int \frac{\mathrm{dQAA}^{*}{ }_{i \text { Fast }}}{\mathrm{d} t}+\mathrm{iQAA}^{*}{ }_{i \text { Fast }},
$$

where $\mathrm{iQAA}^{*}{ }_{i}$ Fast represented the initial pool size and was calculated from the initial total pool size $\left(\mathrm{iQAA}_{i}\right.$ Fast $)$ and the background enrichment in the fast $\mathrm{T} / \mathrm{O}$ pool (eAA $\mathrm{A}_{i \text { BackGround }}$ ), which was assumed to be that of plasma before the start of the infusion:

$$
\mathrm{iQAA}_{i \text { Fast }}=\mathrm{iQAA}_{i \text { Fast }} \times \mathrm{eAA}_{i \text { BackGround }} .
$$

Given this configuration, the natural abundance of ${ }^{13} \mathrm{C}$ was considered in the model through the initial measurements of plasma AA enrichment. One could remove background enrichment by subtracting the preinfusion enrichment from all of the observed data and use those adjusted values to set the initial model conditions, thus operating in excess enrichment mode. Either method yields the same answer.

The isotopic enrichment ratio (IRAA) of the fast $\mathrm{T} / \mathrm{O}$ pool was calculated as

$$
\mathrm{IRAA}_{i \text { Fast }}=\mathrm{QAA}^{*}{ }_{i \text { Fast }} /\left(\mathrm{QAA}_{i \text { Fast }}-\mathrm{QAA}^{*}{ }_{\text {Fast }}\right),
$$

which re-creates the labeled/unlabeled ratio from the MS analyses by subtracting the isotope from the total (labeled plus unlabeled) pool. This enrichment ratio was compared with observed plasma enrichment ratios for model-fitting purposes.

The differential equation describing the change in labeled slow T/O AA with respect to time (dQAA* ${ }_{i}$ Slow $/ \mathrm{d} t ; \mathrm{mmol} / \mathrm{min}$ ) was

$$
\mathrm{dQAA}^{*}{ }_{i \text { Slow }} / \mathrm{d} t=\mathrm{FAA}^{*}{ }_{i \text { FastSlow }}-\mathrm{FAA}^{*}{ }_{i \text { SlowFast }} \text {, }
$$

and the pool size at any point in time $\left(\mathrm{QAA}^{*}{ }_{\text {Slow }}\right)$ by numerical integration of $\mathrm{dQAA}^{*}{ }_{i}{ }_{\text {Slow }} / \mathrm{d} t$ from a specified initial pool size $\left(\mathrm{iQAA}^{*}{ }_{i \text { Slow }}\right)$ was

$$
\mathrm{QAA}^{*}{ }_{i \text { Slow }}=\int \frac{\mathrm{dQAA}^{*}{ }_{\text {Slow }}}{\mathrm{d} t}+\mathrm{iQAA}^{*}{ }_{i \text { Slow }},
$$

where $\mathrm{iQAA}^{*}{ }_{i \text { Slow }}$ was calculated from $\mathrm{QAA}_{i \text { slow }}$ and the assumption that the background enrichment was equal to that of plasma AA:

$$
\mathrm{iQAA}^{*}{ }_{\text {Slow }}=\mathrm{QAA}_{i \text { Slow }} \times \mathrm{eAA}_{i \text { BackGround }} .
$$

Model Inputs, Parameter Derivation, and Parameter Estimation. Required model inputs that must be provided by the user include $\mathrm{F}_{i, \mathrm{ObsInfused}}, t_{\text {InfStart }}$, and $t_{\text {InfStop }}\left(\right.$ Equation 2); $\mathrm{CAA}_{i \text { Fast }}($ Equation 6$) ; \mathrm{BW}$, $\mathrm{CProt}_{\mathrm{BW}}$, and $\mathrm{CAA}_{i \text { Prot }}$ (Equation 10); and the background plasma AA enrichments $\left(\mathrm{eAA}_{i}\right.$ BackGround; Equation 18). Infusion start and stop times and infusion rates were recorded for the experiment. Plasma AA concentrations were assumed to be those of Oltjen et al. (1972). The parameter eAA $i$ BackGround was determined in samples before the isotope infusion.

Model parameters that must be defined or derived from the data include $\mathrm{FAA}_{i \text { Entry }}$ (Equation 1), $\mathrm{KAA}_{i}$ Clearance (Equation 3), $\mathrm{KAA}_{i \text { FastSlow }}$ (Equation 4), $\mathrm{KAA}_{i}$ SlowFast (Equation 5), $\mathrm{VAA}_{i \text { Fast }}$ (Equation 6), and KB$\mathrm{W}_{\mathrm{AA}}$ (Equation 10). Several model parameters can be deduced algebraically if the animals are managed to be in steady state, thus allowing model identification when fitting to the isotopic enrichment data.

Animals herein were frequently fed, and the isotope was administered as a constant infusion in the current work ensuring steady-state conditions. Thus, Equation 1 was set to 0 and $\mathrm{FAA}_{i}$ Clearance was calculated by rearrangement of Equation 1:

$$
\begin{gathered}
\text { FAA }_{i \text { Clearance }}=\mathrm{FAA}_{i \text { Entry }}+\mathrm{FAA}_{i \text { Infused }} \\
+\mathrm{FAA}_{i \text { SlowFast }}-\mathrm{FAA}_{i \text { FastSlow }},
\end{gathered}
$$

where $\mathrm{FAA}_{i}$ Infused is a measured input, $\mathrm{FAA}_{i}$ Entry and FAA $_{i}$ FastSlow are derived by fitting the model to the enrichment data, and $\mathrm{FAA}_{i \text { SlowFast }}-\mathrm{FAA}_{i \text { FastSlow }}=0$ or some predetermined lean body tissue AA deposition rate. Given $\mathrm{FAA}_{i}$ Entry, $\mathrm{KAA}_{i}$ Clearance can be calculated from $\mathrm{iQAA}_{i \text { Fast }}$ (Equation 6):

$$
\begin{aligned}
& \mathrm{KAA}_{i \text { Clearance }}= \\
& \frac{\mathrm{FAA}_{i \text { Entry }}+\mathrm{FAA}_{i \text { Infused }}+\mathrm{FAA}_{i \text { SlowFast }}-\mathrm{FAA}_{i \text { FastSlow }}}{\mathrm{iQAA}_{i \text { Fast }}}
\end{aligned}
$$

If animal growth is assumed to be 0 , Equation 5 could be set equal to Equation 4 or to Equation 4 plus a userdefined net accretion rate. Alternatively, $\mathrm{KAA}_{i}$ FastSlow and $\mathrm{KAA}_{i}$ SlowFast could be calculated from the derived rates and precursor pool sizes:

$$
\begin{aligned}
\mathrm{KAA}_{i \text { FastSlow }} & =\frac{\mathrm{FAA}_{i \text { FastSlow }}}{\mathrm{QAA}_{i \text { Fast }}}, \\
\mathrm{KAA}_{i \text { SlowFast }} & =\frac{\mathrm{FAA}_{i \text { SlowFast }}}{\mathrm{QAA}_{i \text { Slow }}} .
\end{aligned}
$$


Although the animals herein were growing, net AA deposition in lean tissue was unknown and thus assumed to be 0 . The assumption of 0 lean tissue deposition had minimal effect on isotopic clearance rate estimates. However, it is important to note that any net deposition of AA in body tissue would result in a comparable underestimate of entry rates when 0 deposition is assumed.

$\mathrm{VAA}_{i \text { Fast }}$ (Equation 6) is definable from the isotopic enrichment curve provided blood is sampled multiple times in the first $5 \mathrm{~min}$ of the infusion (noted by Maxin et al., 2013), which did not occur in this study. However, the derived entry rates are not sensitive to this parameter (verified in a pilot trial). It approximated to $14.9 \%$ of $\mathrm{BW}(\mathrm{L} / \mathrm{kg})$ across several solves, but the standard errors of the individual estimates were all greater than $50 \%$ of the estimate. Given that blood volume approximates to $8 \%$ of BW (Turner and Herman, 1931), the remainder can be assumed to represent interstitial and cellular space plus the fast $\mathrm{T} / \mathrm{O}$ protein and other recoverable product pools within the cell as discussed above. For this work, it was set to $14.9 \%$ of $\mathrm{BW}$.

Because $\mathrm{dQAA}_{i \text { Fast }} / \mathrm{d} t$ and $\mathrm{dQAA}_{i \text { Slow }} / \mathrm{d} t$ were set to 0 for this work, $\mathrm{QAA}_{i \text { Fast }}$ and $\mathrm{QAA}_{i}$ Slow were fixed and set equal to $\mathrm{iQAA}_{i \text { Fast }}$ and $\mathrm{iQAA}_{i \text { Slow }}$, respectively. $\mathrm{iQAA}_{i \text { Slow }}$ (Equation 10) was calculated using the assumption that body protein is $18.83 \%$ of $\mathrm{BW}$ ( CProt $_{\mathrm{BW}}$, g/g; Williams, 1978) with the AA composition $\left(\mathrm{CAA}_{i \text { Prot }} ; \mathrm{g} / \mathrm{g}\right)$ observed by Williams (1978) and Ainslie et al. (1993). However, as noted above, a portion of this pool likely cannot be identified with a 2-h infusion. Hanigan et al. (2009) used a 3-pool model for 18-h infusions and identified that another pool would be required for longer infusions. Thus, the size of the slow T/O AA pool was allowed to assume a proportion of the overall body protein pool less than 1 as dictated by the isotope kinetics. This fraction $\left(\mathrm{KBW}_{\mathrm{AA}} ; \mathrm{mmol} /\right.$ mmol) was applied across AA and bounded between 0 and 1 to ensure that conservation of mass principles were not violated.

Model predictions of $\mathrm{eAA}_{i \text { Fast }}$ were fitted to the observed plasma AA enrichment ratios for each infusion by maximizing a log-likelihood function using the Nelder Mead optimizer (Press, 2007) encoded in ACSLX (version 3.1.4.2, Aegis Technologies, Huntsville, AL). Adjustable variables included $\mathrm{FAA}_{i \text { Entry }}, \mathrm{KAA}_{i \text { FastSlow }}$, and $\mathrm{KBW}_{\mathrm{AA}}$, with the former 2 variables fit by AA within infusion and the latter across AA within infusion. An initial attempt to fit $\mathrm{KBW}_{\mathrm{AA}}$ by AA was not successful.

Figure 3 shows an example of predicted and observed values for Ile from one infusion. Each AA from each infusion was assessed graphically (as shown in Figure 3) to verify fits and to help identify outliers, which were removed before finalizing the fits. After an initial fit to each infusion, residuals were calculated for each $\mathrm{AA}$, and any data points with absolute residuals $>3 \mathrm{SD}$ were discarded. This represented $1.8 \%$ of all data points and was generally disbursed across infusion times and AA, although a higher proportion were from Phe than any other AA. A final fit to the data was undertaken after removal of the outliers to generate final estimates of FAA $A_{\text {Entry }}$ for each animal and diet.

The derived FAA $i$ Entry were converted to grams per day:

$$
\begin{aligned}
\text { FAA }_{i \text { Entry }}(\mathrm{g} / \mathrm{d}) & =\mathrm{FAA}_{i \text { Entry }} / 1,000 \\
\times 1,440 & \times \mathrm{MW}_{i \mathrm{AA}},
\end{aligned}
$$

where 1,440 is day length in minutes and is checked for outliers. Those within a treatment with an absolute deviation of $2 \mathrm{SD}$ or greater were removed.

Entry rates were used to derive fractional availability values ( $K, \mathrm{~g}$ of AA appearing/g of CP intake) for each test ingredient using the NLMIXED procedure of SAS (version 9.3; SAS Institute Inc., Cary, NC) and the model

$$
\begin{gathered}
\text { FAA }_{i \text { Entry }}(\mathrm{g} / \mathrm{d})=\left(K_{1} \times \mathrm{CP}_{\text {Ingredient } 1}\right)+\ldots \\
+\left(K_{n} \times \mathrm{CP}_{\text {Ingredient } n}\right)+\left(K_{0} \times \mathrm{RDP}_{\text {Diet }}\right) \\
+\left(\mathrm{P}_{n} \times \text { period }_{n}\right)+\text { animal }
\end{gathered}
$$

where $\mathrm{CP}_{\text {Ingredient }}$ represented the observed $\mathrm{CP}$ intake (g/d) deriving from SBM, EAA, casein, FM, BM, or the RPMet in each diet. Animal was treated as a normally distributed random variable with a mean of 0 and a model derived variance. The $\mathrm{FAA}_{i \text { Entry }}$ data were also assumed to be normally distributed, with the mean equal to that predicted by the statistical model and the variance derived by the optimizer. Starting values for $K_{0}$ through $K_{n}$ (content of AA in ingredient $n$ appearing in plasma; $\mathrm{g}$ of $\mathrm{AA} / \mathrm{g}$ of $\mathrm{CP}$ ) were assigned either as discrete values or derived from a grid search with bounds of 0 to 1 (g/g of CP). $\mathrm{RDP}_{\text {Diet }}$ was added to accommodate entry derived from the BD excluding SBM and microbial protein, which could be expected to vary with dietary consumption rates and when postruminal infusions of casein and EAA were substituted for ruminally fermentable SBM. Period was added as a fixed effect with an initial parameter value of 0.1 .

The derived $K$ were subsequently expressed as a percentage of the ingredient AA content as reported by NRC (2001):

$$
\begin{gathered}
\mathrm{AA}_{i} \text { Entry }(\% \text { of ingredient } \mathrm{AA})= \\
\mathrm{K}_{i} / \text { ingredient } \mathrm{AA}_{i} \times 100,
\end{gathered}
$$


where ingredient $\mathrm{AA}_{i}$ represents the ingredient $\mathrm{AA}$ content ( $\mathrm{g}$ of $\mathrm{AA} / \mathrm{g}$ of $\mathrm{CP})$. The RUP entry rate $\left(\mathrm{RUP}_{\text {Entry }}\right)$ in plasma (\% of CP) was derived as the ratio of the sum of $K_{i}$ (excluding $K_{0}$ ) over the sum of ingredient $\mathrm{AA}_{i}$ for each ingredient:

$$
\operatorname{RUP}_{i \text { Entry }}(\% \text { of CP })=\frac{\sum K_{i}}{\sum \text { ingredient } \mathrm{AA}_{i}} \times 100 .
$$

Based on casein observations, the NEAA entry rates seemed to be accurately assessed using this method, although that may not always be the case, particularly if the method is extended to low-protein diets.

Digested RUP can be estimated from RUP Entry $_{\text {by }}$ correcting for first-pass splanchnic utilization of AA (Hanigan et al., 2004a). Casein has been observed to be approximately $95 \%$ digestible in rat studies (Rutherfurd and Moughan, 1998). From that knowledge, first-pass splanchnic AA use can be estimated as

$$
\begin{gathered}
\mathrm{AA}_{i \text { SplUse }}(\%)=\text { casein } \mathrm{AA}_{i \text { Digested }}(\%) \\
- \text { casein } \mathrm{AA}_{i \text { Entry }}(\%) .
\end{gathered}
$$

Digested RUP (dRUP) can then be estimated for each ingredient as

$$
\begin{gathered}
\operatorname{dRUP}(\% \text { of } \mathrm{CP})=\mathrm{RUP}_{\text {Entry }}(\%) / \\
\left(100-\mathrm{AA}_{i \text { Spluse }}\right) .
\end{gathered}
$$

Intestinal RUP digestibility was subsequently estimated as the ratio of dRUP over observed in situ RUP.

Statistical Analyses. All statistical analyses in both experiments 1 and 2 were conducted using SAS version 9.3. Least squares means were calculated for $\mathrm{AA}_{i \text { Entry }}, \mathrm{RUP}$, and dRUP for each ingredient using the GLM procedure of SAS and a model that included the fixed effect of ingredient ( $5 \mathrm{df}$ ). Post-test comparisons of means were made using the LSMEANS statement with the HSD option. For all tests in both experiments 1 and $2, P$-values less than 0.05 were considered significant and values greater than 0.05 and less than 0.10 were considered tendencies.

\section{Experiment 2: In Situ Incubation and Abomasal Infusion}

Animals, Treatments, and Diet Compositions. Two of the rumen-cannulated steers used in experiment 1 were also used for the in situ experiments in experiment 2 , designed to measure indigestible NDF and ruminal protein solubility. The steers were fed a lactating cow ration balanced for more than $40 \mathrm{~L}$ of milk once daily. In the abomasal infusion experiment, 2 nonlactating rumen-cannulated cows were used in a crossover design with 2 periods. The cows were also fed a typical high cow ration to ensure that the AA supply met or exceeded all requirements. Cows were fed every $4 \mathrm{~h}$ and were restricted to $95 \%$ of ad libitum intake to help reduce diurnal variation in plasma AA.

Indigestible NDF Determination. Fecal samples were composited by period and steer, and a subsample was freeze dried. Diet and fecal samples were ground to $2 \mathrm{~mm}$ (Wiley mill, Thomas Scientific, Swedesboro, NJ), subsampled in duplicate, and placed in Dacron bags $(10 \mathrm{~g}$ of diet in $10 \times 20 \mathrm{~cm}$ bags, $5 \mathrm{~g}$ of feces in $5 \times 10$ $\mathrm{cm}$ bags, $50 \mu \mathrm{m}$ porosity; Ankom, Macedon, NY). Bags were incubated for $12 \mathrm{~d}$ in the rumen of the 2 cannulated steers (1 duplicate in each animal) to determine indigestible NDF content. Upon removal, samples were hand washed in cold water followed by washing in a household washing machine on the delicate cold cycle. Washed samples were dried at $55^{\circ} \mathrm{C}$, hand ground using a mortar and pestle, sealed in fiber filter bags $(25 \mu \mathrm{m}$ porosity; Ankom), and assessed for NDF content using an Ankom Fiber Analyzer 200. Residue remaining after the Ankom digestion was assumed to be indigestible $\mathrm{NDF}$ and used to calculate fecal DM output and totaltract apparent nutrient digestibility (Cochran et al., 1986).

Ruminal Protein Solubility. Individual feed ingredients were incubated in the rumen of the 2 cannulated steers. Subsamples (10 g) of BM, FM, RPMet, and SBM were placed into Dacron bags $(10 \times 20 \mathrm{~cm}, 50 \mu \mathrm{m}$ porosity; Ankom), and duplicate bags were incubated in the rumen of each steer (1 replicate per steer) for 0 , $3,9,12,15,24,36,48$, and $72 \mathrm{~h}$. The 0 -h samples were soaked in the rumen for less than 1 min. Upon removal from the rumen, samples were briefly hand washed in cold water and washed in a household washer as above. Washed samples were freeze dried, weighed, and hand ground using a mortar and pestle.

Feed, feces, and the residues from the in situ bags were analyzed for $\mathrm{N}$ content via combustion analysis using a Vario EL cube analyzer (Elementar, Langenselbold, Germany). Soluble N and $\mathrm{N}$ in very small particles leaving the bag at time 0 (A fraction), insoluble $\mathrm{N}$ retained at time 0 (B fraction), and the rate of $\mathrm{B}$ fraction $\mathrm{N}$ loss from the bag $\left(\boldsymbol{K}_{\boldsymbol{d}}\right)$ were estimated using a modification of the method described by Ørskov and McDonald (1979) and with lag time by Robinson et al. (1986) and Dhanoa (1988):

$$
\begin{gathered}
\mathrm{B}=100-\mathrm{A} \\
\mathrm{N}_{t}(\% \text { of initial })=\mathrm{B} \times \mathrm{e}^{\left[-K_{d} \times(\mathrm{h}-\mathrm{lag})\right]} .
\end{gathered}
$$


We attempted to define a nondegradable fraction (C), but the incubation time was not long enough to uniquely define the $\mathrm{C}$ fraction for $\mathrm{BM}$ and $\mathrm{FM}$, and it was not significantly different from 0 for SBM and RPMet; thus, the model was reduced to 2 pools. Parameters were derived using the NLMIXED procedure of SAS 9.3. The variable lag $(\mathrm{h})$ represents the potential time lag before loss begins to occur.

Assessment of the RPMet Intestinal Availability by Abomasal Infusion. The RPMet product was assessed for ruminal protection and intestinal digestibility using an abomasal infusion technique. The RPMet product was ruminally incubated for $8 \mathrm{~h}$ in each of 2 nonlactating ruminally cannulated cows to assess ruminal protection, and the residual material was abomasally infused to assess intestinal digestibility. For each infusion, $55.5 \mathrm{~g}$ of the prototype (72\% DL-Met) was evenly distributed into four $10 \times 20 \mathrm{~cm}$ Dacron bags (50 $\mu \mathrm{m}$ porosity; Ankom). Two additional encapsulated samples $(6.94 \mathrm{~g})$ were incubated in $5 \times 10$ $\mathrm{cm}$ Dacron bags (1 bag, $50 \mu \mathrm{m}$ porosity; Ankom) for $8 \mathrm{~h}$ to determine ruminal disappearance of $\mathrm{N}$. Residue remaining in the larger bags at $8 \mathrm{~h}$ was collected and infused into the abomasum in less than $650 \mathrm{~mL}$ of water over 10 to 15 min via an abomasal infusion line as described above. The infusion line was flushed with 100 $\mathrm{mL}$ of water after infusion of the prototype to ensure quantitative transfer. Unprotected DL-Met $(30 \mathrm{~g})$ was infused without prior rumen incubation as the control treatment.

The smaller bags $(6.94 \mathrm{~g})$ were rinsed 3 times in fresh cold water; excess moisture was removed using a salad spinner, and bags were then stored at $-20^{\circ} \mathrm{C}$ and subsequently freeze dried. Dried residue and a subsample of the source RPMet were ground and analyzed for $\mathrm{N}$ content by combustion as above.

Blood was sampled from an indwelling jugular catheter at $-4,-2,0,0.33,0.67,1,2,4,6,8,10,12$, and 16 $\mathrm{h}$ relative to the completion of the abomasal infusion. Plasma was prepared and stored as described above. Samples were analyzed for AA concentrations by liquid chromatography at the University of Tennessee Department of Chemistry.

Abomasal RPMet Infusion Trial Calculations. Plasma Met concentrations were corrected for preinfusion concentrations, and the area under the curve (AUC) was calculated for each infusion using the trapezoidal rule. The resulting AUC was corrected for $\mathrm{N}$ infused into the abomasum (adj $\left.\mathrm{AUC}_{\mathrm{RPMet}}\right)$. Plasma appearance of Met from RPMet was expressed as a percentage of the appearance of Met from a raw Met infusion using the N-corrected data (adjAUC $\mathrm{RPMet}_{\text {/ }}$ adjAUC $\mathrm{C}_{\text {raw Met }}$ ). Although a portion of the absorbed AA would be removed by the splanchnic tissue before appearance in general circulation, this fractional loss should be the same for the unprotected Met and RPMet, thus canceling out in the calculation, resulting in a true absorption value.

Statistical Analyses. The effect of diet on totaltract N digestibility was tested using the MIXED procedure and a model including the fixed effect of treatment ( $5 \mathrm{df})$, fixed effect of period ( $5 \mathrm{df}$ ), and the random effect of animal ( $5 \mathrm{df}$ ). Differences between percentage $\mathrm{N}$ remaining after 0 and $12 \mathrm{~h}$ of rumen incubation for each ingredient were tested using the GLM procedure and a model including the fixed effect of ingredient ( 5 df). Posttest comparisons of means were made using the LSMEANS statement with the HSD option.

\section{RESULTS AND DISCUSSION}

\section{Intake, Total-Tract Digestibility, and Fecal Output}

Nutrient intake, fecal output, and apparent totaltract digestibilities are summarized in Table 3. The $\mathrm{BD}$ treatment diet had a CP content of $19.5 \% \pm 0.66$, consistent with our formulation goal of $20 \%$ CP. Excepting the casein $(22.7 \% \pm 0.66 \mathrm{CP})$ and EAA $(22.8 \%$ $\pm 0.69 \mathrm{CP})$ treatments, which had a trend for higher $\mathrm{CP}$ content, the other treatments were not significantly different from BD. Therefore, these diets should have all greatly exceeded protein and AA requirements of the animals (NRC, 2001), thus minimizing any risk of differences in AA use for body protein synthesis between diets.

There were no significant differences between the BD treatment and any of the other treatments for DMI, indicating that there were no palatability issues. Waltz et al. (1989) observed considerable sorting of a BM diet compared with an SBM diet. However, inclusion rates in the current study were much lower ( $1.51 \%$ of DM) than those of Waltz et al. (1989; $9.6 \%$ of DM), which likely had an effect.

As anticipated, the BD steers had reduced $\mathrm{N}$ intake $(245.7 \pm 13.60 \mathrm{~g} / \mathrm{d})$ compared with steers on the casein $(305.6 \pm 13.60 \mathrm{~g} / \mathrm{d})$ and EAA $(308.3 \pm 13.60 \mathrm{~g} / \mathrm{d})$ treatments. One would have anticipated the same when substituting BM or FM for SBM given the differences in $\mathrm{CP}$ content; however, those differences were not significant.

Blood meal, FM, and the BD treatments had almost identical total-tract apparent $\mathrm{N}$ digestibilities, suggesting that there were only small - if any - differences in the $\mathrm{N}$ digestibility of the SBM, FM, and BM ingredients. The apparent digestibility findings are not completely consistent with prior studies (Church et al., 1982; Waltz et al., 1989; Goedeken et al., 1990a,b; Klemesrud et al., 1998) where reduced intestinal digestibility of 
Table 3. Least squares means for feed intake and fecal output of DM and $\mathrm{N}$ of Holstein steers fed treatment diets in experiment 1

\begin{tabular}{|c|c|c|c|c|c|c|c|}
\hline Item & \multicolumn{6}{|c|}{ Treatment $^{1}$} & SEM \\
\hline \multicolumn{8}{|l|}{$\mathrm{DM}$} \\
\hline Infusion (kg/d) & & 0.239 & 0.238 & & & & 0.007 \\
\hline Fecal output (kg/d) & $2.92^{\mathrm{xy}}$ & $3.12^{\mathrm{xy}}$ & $3.09^{\mathrm{xy}}$ & $3.01^{\mathrm{xy}}$ & $3.22^{\mathrm{x}}$ & $2.70^{\mathrm{y}}$ & 0.18 \\
\hline \multicolumn{8}{|l|}{ 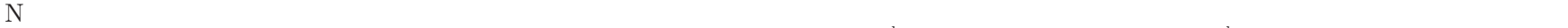 } \\
\hline \multicolumn{8}{|l|}{$\mathrm{CP}$ concentration $(\%)$} \\
\hline Diet, TMR + infusion & $19.54^{\mathrm{a}, \mathrm{xy}}$ & $22.76^{\mathrm{b}, \mathrm{x}}$ & $22.82^{\mathrm{b}, \mathrm{x}}$ & $20.20^{\mathrm{ab}, \mathrm{y}}$ & $20.93^{\mathrm{ab}, \mathrm{xy}}$ & $20.21^{\mathrm{ab}, \mathrm{y}}$ & 0.66 \\
\hline Feces & $17.63^{\mathrm{a}}$ & $18.08^{\mathrm{ab}}$ & $17.71^{\mathrm{a}}$ & $18.46^{\mathrm{b}}$ & $18.55^{\mathrm{b}}$ & $18.02^{\mathrm{ab}}$ & 0.19 \\
\hline
\end{tabular}

${ }^{\mathrm{a}-c}$ Values within a row with different letters are significantly different $(P \leq 0.05)$.

${ }^{\mathrm{x}, \mathrm{y}}$ Values within a row with different letters are considered a trend $(0.05 \leq P \leq 0.1)$.

${ }^{1} \mathrm{BD}=$ base diet; Casein = abomasal infusion of sodium caseinate; EAA = abomasal infusion of Met, Leu, and Ile; FM = feather meal; BM = blood meal; RPMet = rumen-protected Met.

diets containing FM was observed compared with SBM and BM diets. However, FM digestibility can greatly differ based on the amount of blood additions used in the rendering process (Goedeken et al., 1990b), which adds some variation among research findings and may explain the lack of observed digestibility effects herein. The modest substitution levels of FM and BM for SBM in the current work may have also prevented detection of differences in total-tract digestibility. Although the total-tract digestibility estimates were relatively precise (CV of $2.5 \%$ ) when attempting to derive ingredient digestibilities by difference with small dietary substitution rates, these errors are greatly magnified. For example, in the current study, at an FM substitution level of $1.4 \%$ of $\mathrm{DM}$ and a standard error of the mean for apparent digestibility of $1.63 \%$, if one assumed that SBM N was $75 \%$ digestible, the digestibility of the substituted FM would have to be less than $13 \%$ to generate a $2 \mathrm{SD}$ change in total-tract apparent digestibility.

In the case of the infused EAA, digestibility was $100 \%$, which is substantially greater than one would expect for SBM, and thus total-tract apparent CP digestibility increased significantly with substitution of EAA for SBM. Sodium caseinate also has a high intestinal digestibility (Rutherfurd and Moughan, 1998), but it resulted in only a numerical increase in total-tract apparent $\mathrm{N}$ digestibility.

\section{Ruminal Protein Solubility}

The results of the 12-h ruminal incubations are summarized in Table 4. Numerically, FM had the greatest 12-h bag retention ( $81.9 \%$ of CP), which was not different from BM (78.3\%), and both were greater than RPMet $(45.1 \%)$ and SBM (40.9\%). The RPMet product had essentially no soluble $\mathrm{N}$ loss (0 time loss), whereas SBM had the greatest loss at $18.9 \%$. When assessing protein fractions from the time series incubations (Figure 4), the model-derived A fraction for SBM was $15.2 \% \pm 2.64$, which was numerically greater than BM $(11.6 \% \pm 2.12)$ and FM $(11.3 \% \pm 2.12)$. As for the 12 -h analysis, the RPMet product had no loss of soluble N $(-4.8 \% \pm 2.83)$. The RPMet and the SBM numerically had the fastest degradation rates (roughly $7.4 \% / \mathrm{h}$ ) compared with BM $(1.4 \% / \mathrm{h})$ and FM $(0.05 \% / \mathrm{h})$. The NRC (2001) model predicted a particle passage rate of $5.5 \% / \mathrm{h}$. Using that rate with the observed degradation rates, the predicted RUP values would be 36.1, 70.4, 87.9, and $44.6 \%$ for SBM, BM, FM, and RPMet, respectively.

Animal by-products, such as FM, are rich in protein and have intrinsic resistance to the rumen environment, yielding greater proportions of bypass protein (Goedeken et al., 1990a). The current research supports the previous findings. In addition to BM and FM having greater $\mathrm{CP}$ content than SBM, the fractional soluble $\mathrm{N}$ loss and rumen-degradable $\mathrm{N}$ are lower for both $\mathrm{BM}$ and FM compared with SBM. Although prior research has observed ruminal escape protein for FM to be greater than SBM but less than BM (Goedeken et al., 1990a,b), the current research shows the escape protein fraction for FM to be similar to that of BM and greater than that of SBM. The protein fractions and degradation rate for SBM herein are in agreement with NRC (2001) values. For BM, the observed protein fractions and degradation rate are similar to those of the NRC estimated values. For FM, we observed an A fraction of $11.3 \%$, a B fraction of $88.7 \%$, and a degradation rate of $0.55 \% / \mathrm{h}$ compared with NRC (2001) values of $23.4 \% \mathrm{~A}$ fraction, $76.6 \% \mathrm{~B}$ and $\mathrm{C}$ fraction, and $6.6 \% / \mathrm{h}$ degrada- 
Table 4. In situ N evaluation of test ingredients from experiment 2

\begin{tabular}{lcccc}
\hline & \multicolumn{4}{c}{ Ingredient $^{1}$} \\
\cline { 2 - 5 } Item & SBM & BM & FM & RPMet \\
\hline 12-h incubation & & & & \\
CP (\% of DM) & 52.4 & 104.7 & 89.0 & 70.4 \\
Insoluble N (\% of total N) & $81.1^{\mathrm{a}}$ & $87.9^{\mathrm{b}}$ & $88.9^{\mathrm{b}}$ & $100.3^{\mathrm{c}}$ \\
N remaining after 12 h (\% of total N) & $40.9^{\mathrm{a}}$ & $78.3^{\mathrm{b}}$ & $81.9^{\mathrm{b}}$ & $45.1^{\mathrm{a}}$ \\
72-h time series incubation & & & & \\
A fraction (\% of total N) & 15.2 & 11.6 & 11.3 & -4.9 \\
B fraction ${ }^{2} \%$ of total N) & 84.8 & 88.4 & 88.7 & 104.9 \\
$K_{d}^{3}$ & 7.41 & 1.41 & 0.05 & 7.44 \\
RUP $^{4}$ (\% of total N) & 36.1 & 70.4 & 87.9 & 44.6 \\
\hline
\end{tabular}

${ }^{a-c}$ Values within a row with different superscripts significantly differ $(P<0.05)$.

${ }^{1} \mathrm{SBM}=$ soybean meal; $\mathrm{BM}=$ blood meal; $\mathrm{FM}=$ feather meal; RPMet $=$ rumen-protected Met.

${ }^{2}$ Defined as $100-\mathrm{A}$.

${ }^{3} \mathrm{~N}(\%) / \mathrm{h}$

${ }^{4}$ Predicted using NRC (2001) with an assumed rate of passage of 5.5\%/h.

tion rate. These differences could be due to variable content of blood in the FM across the studies. The FM used herein appears to be much more resistant to ruminal degradation than suggested by the NRC.

\section{Plasma AA Appearance Rates}

Model-derived plasma AA entry rates $(\mathrm{mmol} / \mathrm{min})$ for each diet are shown in Table 5. The standard errors for the entry rate estimates were generally less than 10\% except for Met ( 22\%), Asp (26\%), and Tyr $(13 \%)$. This variation reflects both analytical and animal sources, with the latter arising at least in part from differences in DMI. Derived entry rates were generally greater for each diet than the predicted duodenal AA flow rates from the NRC model and that derived from ingredient intakes as previously observed by Borucki Castro et al. (2008) and Maxin et al. (2013). This likely reflects the inability to derive precise estimates of isotope incorporation into slowly turning over body protein pools from a 2-h infusion. The parameter KB$\mathrm{W}_{\mathrm{AA}}$ (see Equation 10) solved to a mean of 0.00084 \pm 0.0005 across infusions, indicating that a small proportion of the overall body AA pool was required to exchange with the fast AA pool over the infusion time frame to explain the data. This is consistent with prior

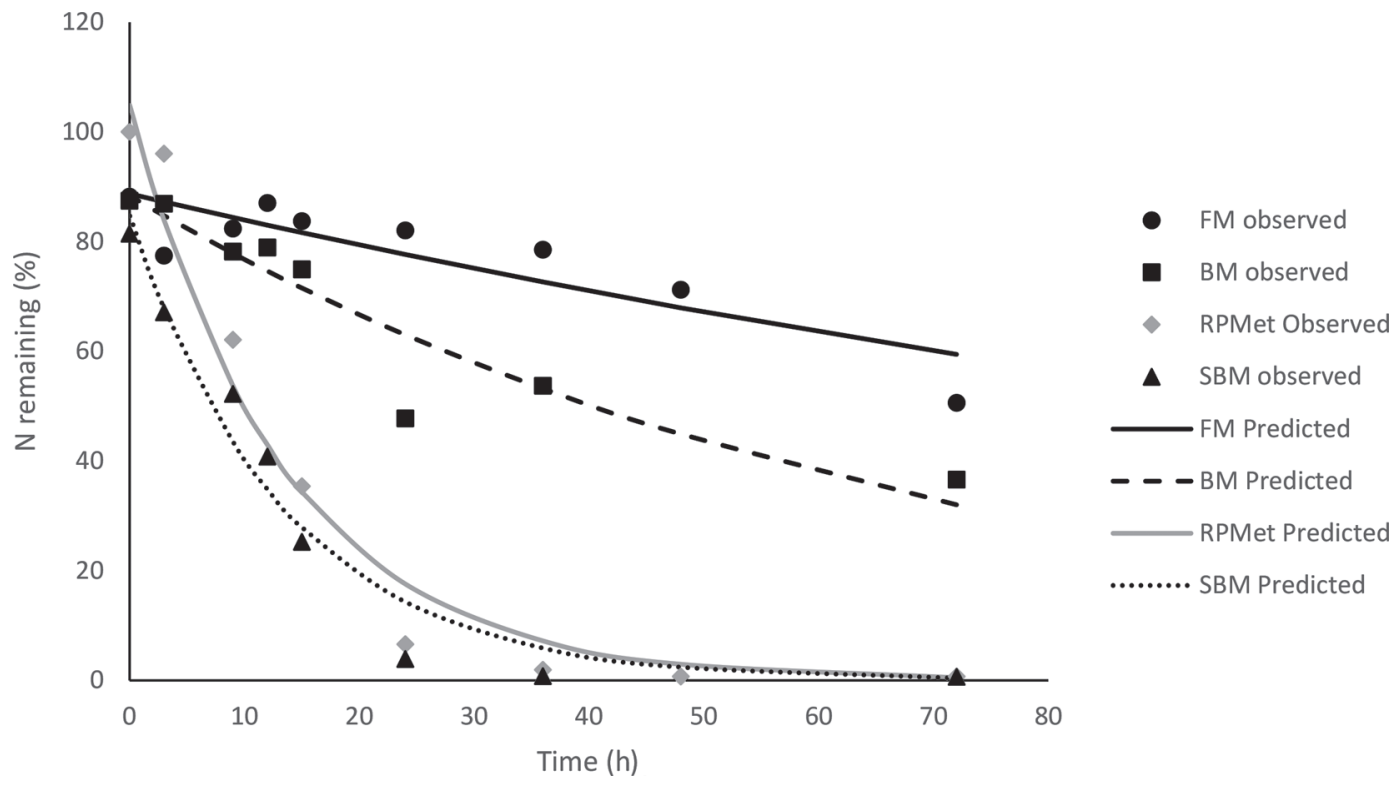

Figure 4. Observed and predicted in situ protein degradation results from experiment 2 for the test ingredients. $\mathrm{FM}=$ feather meal; BM $=$ blood meal; RPMet = rumen-protected Met; SBM = soybean meal. 
observations that blood enrichment continued to slowly increase even after $30 \mathrm{~h}$ of isotope infusion, indicating that tissue protein is not fully labeled (Hanigan et al., 2009). They estimated it would take approximately 40 $\mathrm{d}$ to fully label all of the tissue protein based on a 3 -pool model. As a 2-pool model was used herein, the incorporation of label into the very slow $\mathrm{T} / \mathrm{O}$ pools would be underestimated, which results in an overestimate of total entry rates. The derived $\mathrm{KBW}_{\mathrm{AA}}$ resulted in a slow $\mathrm{T} / \mathrm{O}$ pool size estimate that was roughly 6 times the size of the fast $\mathrm{T} / \mathrm{O}$ pool, which is a small fraction of the total-body AA. However, the portion of the entry rate that is due to this overestimate will segregate into the intercept when deriving fractional entry rates for each ingredient in the diet, as it should be constant across diets. Thus, it does not compromise derivation of ingredient values, only the estimate of intercept terms such as RDP.

When estimates of $\mathrm{AA}_{\text {Entry }}$ for each ingredient were derived from the dietary entry rates (Tables 6 and 7), the standard error of the estimates averaged $14 \%$ across the EAA. It was the greatest for Met, reflecting the lower proportions of Met in the feed ingredients and slightly greater absolute standard error. Expressing the standard error as a proportion of the ingredient CP, which is the measurement of interest, the variance averaged $8 \%$, with Met at $14 \%$.

Initially, a constant intercept term was used to represent the AA entry derived from the BD portion of the diet. However, because BD consumption was not constant across treatments and because the EAA and casein infusions were not subjected to ruminal metabolism, we found that the use of a variable intercept term improved model fits and precision. It is logical to expect this term to represent BD RUP plus the microbial $\mathrm{CP}$ contributions to EAA appearance, but attempts to predict those entities directly from dietary terms result in poor model precision. We found that dietary RDP estimates provided significant improvements in model fits and precision. Amino acid entry rates associated with this term (the slope coefficient) were generally greater than predicted from microbial protein plus BD RUP, which likely reflects the incomplete label recovery as noted above or errors of predictions of microbial AA and BD RUP flows.

Another challenge that was encountered was associated with the experimental design. Substitution of test ingredients for SBM within the BD resulted in 3 ingredients varying across 2 diets: variable intakes of $\mathrm{BD}$ minus SBM, varying SBM intake, and varying intakes of the test ingredient. This resulted in 7 unknowns to be derived from 6 treatments in the overall study. It would have been mathematically advantageous to add the ingredient of interest on top of BD, thus effectively substituting the ingredient of interest for $\mathrm{BD}$ rather than substituting for SBM within BD so that any reduction in $\mathrm{BD}$ intake could be directly accommodated based on direct observations from the $\mathrm{BD}$ treatment. In the current work, we were forced by the experimental design to represent SBM and BD minus SBM as separate entities. This approach appeared to work and resulted in determinations of AA entry rates for SBM. However, the entry rates for SBM were highly correlated with RDP values and proved to be biased. Had we used larger substitution rates, we likely could have achieved unbiased estimates of all 7 components of the diet.

Derived entry rates for the infused EAA expressed as a percentage of abomasally infused Ile, Leu, and Met were 93 to $94 \%$. Recoveries of casein EAA in plasma were similar to those observed by Hanigan et al. (2004a), averaging $87 \%$ and ranging from 86 to $93 \%$ excepting

Table 5. Least squares means of apparent plasma entry rates $(\mathrm{mmol} / \mathrm{min})$ for each diet derived from fits of the isotope dilution model to observed isotope ratios in experiment 1

\begin{tabular}{lccccccc}
\hline & \multicolumn{7}{c}{ Treatment $^{1}$} \\
AA & BD & Casein & EAA & BM & FM & RPMet & \multirow{2}{*}{ SE } \\
\cline { 2 - 6 } & 1.27 & 1.27 & 1.91 & 1.26 & 1.29 & 1.21 & 0.09 \\
Ile & 1.78 & 1.63 & 2.27 & 1.83 & 1.71 & 1.49 & 0.15 \\
Leu & 1.78 & 1.55 & 1.39 & 1.95 & 1.63 & 1.57 & 0.18 \\
Lys & 1.64 & 0.79 & 1.93 & 0.85 & 0.81 & 0.94 & 0.26 \\
Met & 1.38 & 1.06 & 1.29 & 1.21 & 1.22 & 1.18 & 0.10 \\
Phe & 1.11 & 1.06 & 0.95 & 1.14 & 1.01 & 1.11 & 0.10 \\
Thr & 1.85 & 1.88 & 1.49 & 2.04 & 1.89 & 1.70 & 0.11 \\
Val & 5.04 & 4.64 & 4.88 & 5.16 & 5.10 & 5.36 & 0.33 \\
Ala & 1.22 & 0.83 & 1.27 & 0.87 & 1.13 & 1.23 & 0.28 \\
Asp & 5.14 & 5.02 & 4.80 & 5.16 & 5.17 & 5.03 & 0.37 \\
Gly & 1.08 & 1.04 & 0.94 & 1.04 & 1.08 & 1.02 & 0.07 \\
Pro & 0.66 & 0.55 & 0.75 & 0.73 & 0.76 & 0.68 & 0.09 \\
Tyr & & &
\end{tabular}

${ }^{1} \mathrm{BD}=$ base diet; Casein = abomasal infusion of sodium caseinate; EAA = abomasal infusion of Met, Leu, and Ile; $\mathrm{BM}=$ blood meal; $\mathrm{FM}=$ feather meal; RPMet $=$ rumen-protected Met. 
Table 6. Essential AA plasma entry rates associated with each ingredient for steers fed the experimental diets in experiment 1

\begin{tabular}{|c|c|c|c|c|c|c|}
\hline $\mathrm{AA}$ & Ingredient $^{1}$ & $\begin{array}{l}\text { Ingredient } \mathrm{AA}^{2} \\
(\% \text { of } \mathrm{CP})\end{array}$ & $\begin{array}{c}\text { Plasma AA entry } \\
(\% \text { of } \mathrm{CP})\end{array}$ & $\mathrm{SE}$ & $P>|\mathrm{t}|^{3}$ & $\begin{array}{c}\text { Plasma AA entry } \\
(\% \text { of ingredient AA) }\end{array}$ \\
\hline \multirow[t]{4}{*}{ Ile } & FM & 4.34 & 2.17 & 0.24 & 0.0003 & 50.00 \\
\hline & $\mathrm{BM}$ & 1.26 & 0.56 & 0.17 & 0.0207 & 44.44 \\
\hline & EAA & 51.44 & 47.91 & 0.30 & $<0.0001$ & 93.13 \\
\hline & Casein & 5.5 & 4.04 & 0.29 & $<0.0001$ & 73.45 \\
\hline \multirow[t]{4}{*}{ Leu } & FM & 8.44 & 4.07 & 0.39 & 0.0001 & 48.22 \\
\hline & BM & 12.82 & 3.87 & 0.25 & $<0.0001$ & 30.18 \\
\hline & EAA & 30.50 & 28.72 & 0.40 & $<0.0001$ & 94.16 \\
\hline & Casein & 10.2 & 8.97 & 0.46 & $<0.0001$ & 87.94 \\
\hline \multirow[t]{5}{*}{ Met } & FM & 0.84 & 0.44 & 0.32 & 0.2244 & 52.38 \\
\hline & $\mathrm{BM}$ & 1.17 & 0.71 & 0.21 & 0.0217 & 60.68 \\
\hline & RPMet & 100 & 9.90 & 1.51 & 0.0013 & 9.90 \\
\hline & EAA & 18.05 & 16.78 & 0.39 & $<0.0001$ & 92.96 \\
\hline & Casein & 3.3 & 2.90 & 0.38 & 0.0006 & 87.87 \\
\hline \multirow[t]{3}{*}{ Lys } & FM & 2.90 & 1.65 & 0.38 & 0.0081 & 56.89 \\
\hline & $\mathrm{BM}$ & 8.98 & 4.77 & 0.28 & $<0.0001$ & 53.11 \\
\hline & Casein & 8.8 & 7.55 & 0.50 & $<0.0001$ & 85.79 \\
\hline \multirow[t]{3}{*}{ Phe } & FM & 4.83 & 2.45 & 0.44 & 0.0027 & 50.72 \\
\hline & $\mathrm{BM}$ & 6.85 & 3.40 & 0.30 & $<0.0001$ & 49.63 \\
\hline & Casein & 5.9 & 5.12 & 0.58 & 0.0003 & 86.77 \\
\hline \multirow[t]{3}{*}{ Thr } & FM & 4.70 & 2.74 & 0.44 & 0.0016 & 58.29 \\
\hline & $\mathrm{BM}$ & 4.34 & 2.25 & 0.28 & 0.0005 & 51.84 \\
\hline & Casein & 4.8 & 4.47 & 0.61 & 0.0008 & 93.12 \\
\hline \multirow[t]{3}{*}{ Val } & FM & 6.76 & 3.55 & 0.43 & 0.0005 & 52.51 \\
\hline & $\mathrm{BM}$ & 8.68 & 3.72 & 0.29 & $<0.0001$ & 42.85 \\
\hline & Casein & 7.0 & 6.46 & 0.54 & $<0.0001$ & 92.28 \\
\hline
\end{tabular}

${ }^{1} \mathrm{FM}=$ feather meal; $\mathrm{BM}=$ blood meal; EAA = abomasally infused Met, Leu, and Ile; Casein = abomasally infused sodium caseinate; RPMet $=$ rumen-protected Met.

${ }^{2} \mathrm{BM}$ and FM AA concentrations are from Cunningham et al. (1994); casein AA concentrations are from Choung and Chamberlain (1995).

${ }^{3}$ Test of plasma AA entry difference from 0 .

Ile, which was 73\%. These are nominally lower than for (Rutherfurd and Moughan, 1998), use of EAA durthe EAA because casein is not completely digestible. ing absorption would be $21 \%$ for Ile and range from If one corrects the casein recoveries for digestibility 1 to $8 \%$ for the other EAA. The difference between

Table 7. Nonessential AA apparent plasma entry rates associated with each ingredient for steers fed the experimental diets in experiment 1

\begin{tabular}{|c|c|c|c|c|c|c|}
\hline $\mathrm{AA}$ & Ingredient $^{1}$ & $\begin{array}{l}\text { Ingredient } \mathrm{AA}^{2} \\
(\% \text { of } \mathrm{CP})\end{array}$ & $\begin{array}{l}\text { Plasma entry } \\
\text { (\% of CP) }\end{array}$ & $\begin{array}{l}\text { Plasma entry } \\
\text { (SE) }\end{array}$ & $P>|\mathrm{t}|^{3}$ & $\begin{array}{c}\text { Plasma entry } \\
\text { (\% of ingredient AA) }\end{array}$ \\
\hline \multirow[t]{3}{*}{ Ala } & FM & 4.80 & 1.66 & 0.31 & 0.0031 & 34.58 \\
\hline & BM & 6.30 & 4.65 & 0.21 & $<0.0001$ & 73.80 \\
\hline & Casein & 3.40 & 2.97 & 0.45 & 0.0012 & 87.35 \\
\hline \multirow[t]{3}{*}{ Asp } & FM & 5.70 & 1.97 & 0.24 & 0.0005 & 34.56 \\
\hline & BM & 7.90 & 6.41 & 0.18 & $<0.0001$ & 81.13 \\
\hline & Casein & 7.70 & 6.78 & 0.34 & $<0.0001$ & 88.05 \\
\hline \multirow[t]{3}{*}{ Gly } & FM & 6.60 & 2.80 & 0.44 & 0.0015 & 42.42 \\
\hline & $\mathrm{BM}$ & 3.60 & 2.26 & 0.28 & 0.0005 & 62.77 \\
\hline & Casein & 2.10 & 1.94 & 0.63 & 0.0278 & 92.38 \\
\hline \multirow[t]{3}{*}{ Pro } & FM & 8.40 & 2.20 & 0.40 & 0.0028 & 26.19 \\
\hline & BM & 3.00 & 2.07 & 0.26 & 0.0006 & 69.00 \\
\hline & Casein & 10.20 & 7.66 & 0.48 & $<0.0001$ & 75.09 \\
\hline \multirow[t]{3}{*}{ Tyr } & FM & 2.90 & 2.1 & 0.24 & 0.0003 & 72.41 \\
\hline & BM & 2.20 & 1.2 & 0.17 & 0.0007 & 54.54 \\
\hline & Casein & 6.20 & 5.94 & 0.32 & $<0.0001$ & 95.80 \\
\hline
\end{tabular}

${ }^{1} \mathrm{BM}=$ blood meal; $\mathrm{FM}=$ feather meal; Casein = abomasally infused sodium caseinate.

${ }^{2} \mathrm{BM}$ and FM AA concentrations are from Cunningham et al. (1994); casein AA concentrations are from Choung and Chamberlain (1995).

${ }^{3}$ Test of plasma AA entry difference from 0 . 
the infused amounts after correction for digestibility and that entering plasma reflects first-pass use of the EAA during absorption and passage through the liver. Methionine use was very similar to the $4 \%$ use reported by Maxin et al. (2013), and the range of use for the EAA were similar to portal-drained viscera (PDV) use during absorption reported by Hanigan et al. (2004a). However, they are greater than observations of MacRae et al. (1997b), which were essentially 0 across the gut. El-Kadi et al. (2006) reported net use of AA by the mesenteric drained viscera in sheep of $12,-1$, and $0 \%$ for Ile, Leu, and Met, respectively, when casein was assumed to be $100 \%$ digestible and tissue use was solely from the absorbed supply (no arterial use).

Single-pass use by liver ranges from essentially 0 for the BCAA to $3 \%$ for Lys, $6 \%$ for Thr, and $12 \%$ for Met (calculated as hepatic blood flow/clearance rate plus blood flow; Arriola Apelo et al., 2014b). Combining the PDV and hepatic values from the independent PDV and hepatic work yields similar first-pass use as derived herein for most of the EAA, with Met use being somewhat lower in the current work and Ile use being greater. First pass prevents direct estimation of absorption using this technique. If the isotope were infused into the mesenteric artery rather than the jugular vein, hepatic use would be removed from the estimate, leaving only PDV use. Infusion of the isotope into the abomasum could avoid the problem of use during absorption; however, it must mix and be absorbed from the same length of intestine as the dietary protein. If free AA are infused, these would presumably be absorbed very rapidly over a short segment of the intestine and thus not fully mixed with the entire absorption stream, which would underestimate PDV use. Use of unhydrolyzed labeled algae infused into the abomasum may more closely mimic feed protein and likely would provide a closer estimate of the true rate of absorption. However, one must know the true digestibility of each $\mathrm{AA}$ in the algae and the infusion would require placement of a ruminal or abomasal cannula, which may prevent use of the technique in larger production studies. From an animal production standpoint, the current method provides an estimate of the fraction of EAA that are available for production, which is the goal of our prediction systems.

Unlike abomasally infused ingredients, ingredients consumed in the diet are subject to ruminal degradation. Thus, plasma appearance represents the fraction of feed EAA that escapes ruminal degradation, is digested and absorbed from the intestine, and is not utilized during transit through the splanchnic tissues. Although there is considerable focus on ruminal degradation, the net result of the 3 processes results in a surprisingly small fraction of total ingredient EAA that are absorbed and available for postabsorptive use. However, one must consider that a significant proportion of the $\mathrm{N}$ degraded in the rumen is captured in microbial protein and delivered to the animal in that form. Thus, the net postabsorption delivery of approximately half of the ingredient EAA associated with their respective RUP fraction is consistent with our expectations.

Errors of estimating the supply of individual EAA for FM and BM averaged 15 and $9 \%$ of the mean entry rates, respectively. Although these may not seem to be overly precise, efforts to derive $\mathrm{N}$ digestibility values for the individual ingredients from total-tract digestibility observations failed to generate any meaningful data, at least partially due to the aggregation of errors when deriving by difference and to the secretion of endogenous proteins along the gut. Therefore, the fact that the matrix solved for the ingredients and generated individual EAA data with less than $10 \%$ variance (\% of ingredient $\mathrm{CP}$ ) underscores the value of this procedure.

The RPMet ingredient solved for a plasma entry rate of $9.9 \%$. This estimate is considerably less than the $42 \%$ availability estimate derived from an abomasal pulse infusion of the product. There was variation between the 2 cows (Figure 5), but clearly the large increase in blood concentrations after the pulse infusion indicates that a significant fraction of the Met was available to the animal. Compared with the other AA, there was greater variance for Met entry rate determinations (Table 5), thus introducing more error into the matrix of entry rates. However, model fits to the time series enrichment data had only slightly greater errors of prediction, and there were no clear outlier infusions. It is unclear whether one or both of these challenges contributed to the apparent errors of determination. It is also possible that the physical processes of mastication and swallowing and abrasion in the rumen released more of the encapsulated Met in experiment 1 than occurred within the nylon bag used to estimate ruminal availability in experiment 2. Another potential problem with the RPMet and EAA treatments that was considered is that the RPMet used was an equal mix of D and $\mathrm{L}$ isomers, whereas the algae-derived tracer was all L-Met, and thus the derived entry rates are for the L isomer. The conversion of $\mathrm{D}$ to $\mathrm{L}$ is not instantaneous; clearance rates of the $\mathrm{D}$ form are 6 times longer than those of the L form (8 vs. 54 min; Lapierre et al., 2012). Given that the EAA were infused for $24 \mathrm{~h}$ and the RPMet was fed for $10 \mathrm{~d}$ before the start of the isotope infusion, it seems highly unlikely that the conversion of $\mathrm{D}$ to $\mathrm{L}$ was not in steady state. This is supported by the observation that the EAA mix, which contained a mix of D and L Met isomers, solved for the expected Met entry rates. Based on this, one must conclude that D to L conversion of Met did not contribute to the ap- 


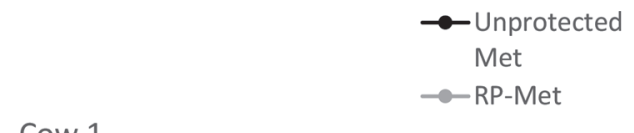

Cow 1

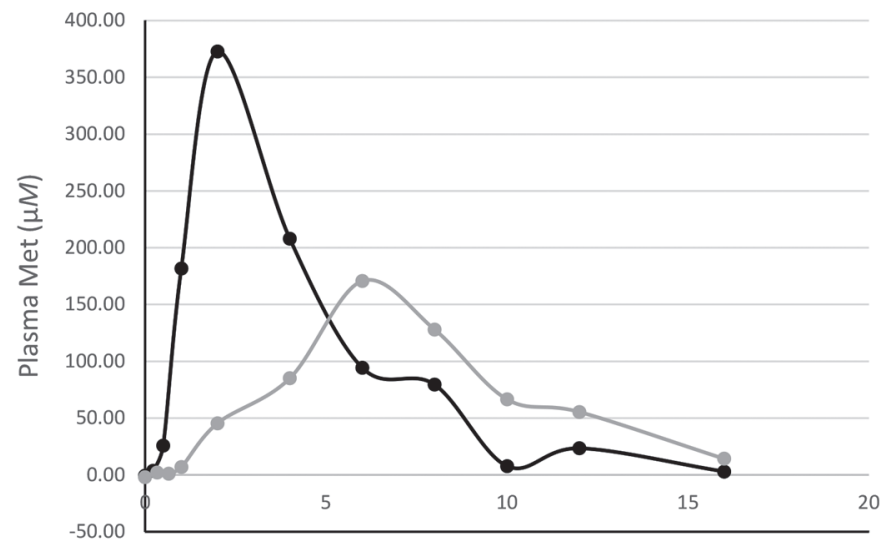

Cow 2

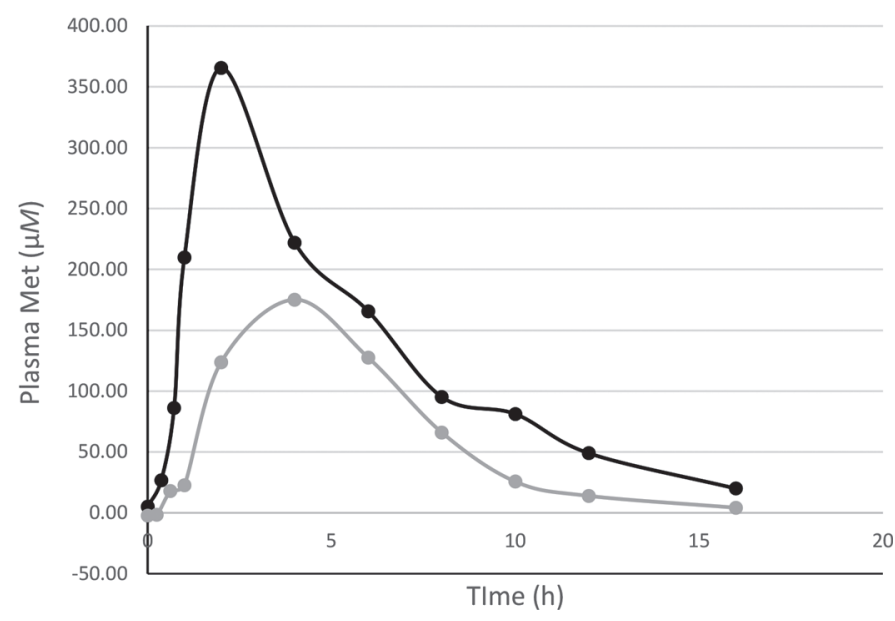

Figure 5. Observed plasma Met concentrations in each of 2 cows following an abomasal bolus of the residual rumen-protected Met (RPMet) prototype after $8 \mathrm{~h}$ of ruminal incubation or unprotected Met in experiment 2.

parently aberrant RPMet determination. Further work is needed to determine the source of this discrepancy between the 2 methods.

Comparing the EAA entry rate profiles of BM and FM CP, the latter is numerically a better source of Ile, Leu, and Thr and a poorer source of Met, Lys, Phe, and Val. Goedeken et al. (1990b) determined that after a 12-h rumen incubation, FM EAA profiles were very similar to their undigested counterpart. These findings suggest that the undigested EAA profile of FM can be used to predict rumen bypass AA content, which has also been supported by Goedeken et al. (1990a). However, Klemesrud et al. (2000) determined that the escape EAA content of FM was more variable (43$130 \%$ of each AA remained after ruminal incubation).
Goedeken et al. (1990b) found that the branched-chain AA Phe and Thr were more highly protected during ruminal incubation. Although we did not assess AA remaining after ruminal incubation, the overall availability to the animal was generally greater for the EAA than the NEAA excepting Tyr, and Lys and Thr were greatest for the EAA as a proportion of that contained in the source ingredient.

It was surprising that estimates of NEAA appearance from casein reflected their composition in casein (Table 7). Entry rates for NEAA represent the sum of absorption and synthesis within the body. Measurements of entry rate reflect irreversible loss of the label from the system. If label is recycled, this is transparent to the measurement. Recycling of label within an AA is not problematic. However, if label from one AA is transferred to another, which can occur for the NEAA, this would distort the entry rate estimates. This is likely of minimal significance for Ala, Asp, and Gly, which are synthesized from precursor pools whose $\mathrm{T} / \mathrm{O}$ is dominated by non-AA carbon fluxes resulting in significant additional dilution of the label upon entry (Freetly et al., 1993; Hanigan and Baldwin, 1994; Hanigan et al., 2001, 2004b), thus minimizing label recycling. This is supported by the observations of entry rates from casein that are almost identical on a proportional basis to those of EAA for these $3 \mathrm{AA}$. It is of greater concern for Pro and Tyr, which are synthesized directly from Glu and Phe without passing through another pool. In the case of Pro, the proportional recovery from casein was less than that for the EAA, which is consistent with expectations if label is recycled. Recovery of Tyr is greater than the EAA, suggesting that no label recycling occurred.

The NEAA plasma entry rates as a proportion of the ingredient AA content were generally well below those for EAA for FM. It cannot be determined whether the decline was due to differential ruminal catabolism of the AA, poor digestibility, a change in splanchnic catabolic rate, or a change in whole-body synthesis rates. There are several reports of AA composition of in situ residues of FM and BM (Goedeken et al., 1990b; Klemesrud et al., 1997, 1998, 2000); unfortunately, none of those reports included the NEAA data. Cunningham et al. (1994) observed generally increasing duodenal EAA flows and declining NEAA flows as increasing amounts of a 3:1 mix of FM and BM were substituted for urea and corn meal in dairy cattle diets. Waltz et al. (1989) observed significantly lower intestinal digestibilities for duodenal Asp, Ser, Glu, Pro, and Ala when FM was included in the diet compared with the diets containing SBM and BM. It is also possible that the NEAA were catabolized by the gut tissue during absorption or that whole-body synthesis rates changed. Thus, although the 
Table 8. Least squares means of protein entry rates predicted from entry of all AA or from Ile, Leu, Met, Lys, Phe, Thr, and Val for each ingredient and calculated digestible RUP and digestibility of the RUP for each ingredient in experiment 1

\begin{tabular}{|c|c|c|c|c|c|}
\hline Ingredient $^{1}$ & $\begin{array}{c}\text { Plasma RUP entry } \\
\text { (\% of CP) }\end{array}$ & $\mathrm{SE}$ & $\begin{array}{l}\text { Absorbed RUP }{ }^{2} \\
(\% \text { of } \mathrm{CP})\end{array}$ & $\begin{array}{c}\text { Intestinal } \\
\operatorname{DC}_{\text {RUP-Kd }}{ }^{3}(\%)\end{array}$ & $\begin{array}{c}\text { Intestinal } \\
\operatorname{DC}_{\mathrm{RUP}-12 \mathrm{~h}}{ }^{4}(\%)\end{array}$ \\
\hline \multicolumn{6}{|l|}{ From all AA } \\
\hline $\mathrm{FM}$ & $48.3^{\mathrm{a}}$ & 4.56 & 52.6 & 60 & 64 \\
\hline $\mathrm{BM}$ & $56.2^{\mathrm{a}}$ & 4.56 & 61.2 & 87 & 78 \\
\hline RPMet & $9.9^{\mathrm{a}}$ & 15.79 & 10.8 & 24 & 24 \\
\hline $\mathrm{EAA}$ & $93.4^{\mathrm{b}}$ & 9.12 & 101.8 & - & - \\
\hline Casein & $87.2^{\mathrm{b}}$ & 4.56 & 95.0 & - & - \\
\hline \multirow{2}{*}{\multicolumn{6}{|c|}{$\begin{array}{l}\text { From Ile, Leu, Met, Lys, } \\
\text { Phe. Thr and Val }\end{array}$}} \\
\hline & & & & & \\
\hline $\mathrm{FM}$ & $52.7^{\mathrm{a}}$ & 4.81 & 57.5 & 65 & 70 \\
\hline $\mathrm{BM}$ & $47.5^{\mathrm{a}, \mathrm{x}}$ & 4.81 & 51.8 & 74 & 66 \\
\hline RPMet & $9.9^{\mathrm{b}, \mathrm{y}}$ & 12.73 & 10.8 & 24 & 24 \\
\hline EAA & $93.4^{\mathrm{c}}$ & 7.35 & 101.8 & - & - \\
\hline Casein & $86.7^{\mathrm{c}}$ & 4.81 & 95.0 & - & - \\
\hline
\end{tabular}

${ }^{\mathrm{a}-\mathrm{c}}$ Values within a column with different superscripts significantly differ $(P<0.05)$.

${ }^{\mathrm{x}, \mathrm{y}}$ Values within a column with different letters are considered a trend $(0.05 \leq P \leq 0.1)$.

${ }^{1} \mathrm{FM}=$ feather meal; $\mathrm{BM}=$ blood meal; RPMet $=$ rumen-protected Met; EAA = abomasal infusion of Met, Leu, and Ile; Casein = abomasal infusion of sodium caseinate.

${ }^{2}$ Values were calculated from total AA appearance and $8.27 \%$ use of AA by gut tissue during absorption.

${ }^{3}$ RUP digestibility calculated from observed digested RUP and RUP as RUP $=B_{\text {fraction }} \times\left[K_{p} /\left(K_{d}+K_{p}\right)\right]$, where $\mathrm{K}_{\mathrm{p}}$ represents the rate of passage, which was assumed to be $5.5 \% / \mathrm{h}$, and $\mathrm{K}_{\mathrm{d}}$ represents the rate of $\mathrm{N}$ degradation of the B fraction as observed in experiment 2.

${ }^{4}$ RUP digestibility calculated from observed digested RUP and 12-h in situ-determined RUP.

NEAA results suggested that entry rates may reflect absorption, this was not the case for all treatments and experimental designs, and NEAA entry rates should generally be considered a combination of absorption and whole-body synthesis. Over time, a clearer picture of the regulation of NEAA synthesis and splanchnic catabolism may arise through reporting of these values, allowing deconvolution of the data.

\section{Absorbed Protein Estimates}

The mean of the individual AA plasma entry rates can be used to estimate protein entry rates (Table 8). Based on these values, $56.2 \% \pm 4.56$ of $\mathrm{BM} \mathrm{CP}$ and $48.3 \% \pm 4.56$ of FM CP entered the plasma pool. Although there were numerical differences, they were not statistically significant. The loss of AA during absorption averaged $8.3 \%$ for casein. One can assume the same use for other proteins to calculate absorbed RUP from plasma entry, yielding values of 52.6 and $61.2 \%$ of CP for FM and BM (Table 8). From NRC (2001), multiplication of RUP at a DMI of $2 \%$ of BW by the reported RUP digestibility values yields absorbed protein estimates from 46 to $53 \%$ for FM and from 46 to $56 \%$ for BM, which encompass the FM estimates herein and are slightly less than the BM estimates. Waltz et al. (1989) observed slightly greater digestible RUP for FM.

Using either the 12-h in situ RUP estimate or an NRC (2001) estimate based on the in situ degradation data and a passage rate of $5.5 \% / \mathrm{h}$ (Table 4 ), intestinal digestibility of BM and FM was predicted to be approximately 82 and $62 \%$, respectively. Apparent ileal AA digestibility for FM assessed in male broiler chicks was roughly $60 \%$ (Ravindran et al., 1999), which is consistent with observed reductions in dietary $\mathrm{CP}$ digestibility reported by Waltz et al. (1989) when FM replaced SBM and with the calculated values herein. These findings also agree with the total-tract measurements in sheep reported by Goedeken et al. (1990a).

An assessment of total digestibility of BM and FM from the same supplier during the same year as used for the current ingredients was conducted using cecectomized roosters (personal communication from C. Stoffel, Papillon, Easton, MD) and found total AA digestibility of $95.2 \%$ for BM and $81.3 \%$ for FM. A comparable value from the work herein was yielded by the summation of the in situ ruminal degradation and the absorbed RUP values. Those values for BM were 83 and $91 \%$ when using the 12 -h in situ or the $K_{d}$-based estimates of RUP, respectively, and the corresponding values for FM were 71 and $65 \%$. In the case of the 12 -h incubations, the estimates from the current work were approximately 10 percentage units less than observed from the roosters but directionally consistent. When using the $K_{d}$ based values, the estimates from the current work for BM and FM were approximately 4 and $15 \%$ units less, respectively, than observed from the roosters but were also directionally consistent. A comparison of digestibilities 
assessed in young growing chicks or using standardized ileal availability methods with those derived using cecectomized roosters showed lower digestibility in the intact animals for some ingredients (Garcia et al., 2007; Kim et al., 2011). There are several reasons why a difference among the techniques may be observed. When fed, the ingredients are not finely ground as required for the rooster assay (Boucher et al., 2009). The reduced surface area of the fed ingredient may contribute to a reduction in overall digestibility; however, Titgemeyer et al. (1990) observed similar results between apparent intestinal disappearance in steers and digestibility of duodenal contents in cecectomized roosters. It is also possible that the different lots of ingredients differed. Additional work across ingredients using the same lot of ingredients for both assays is needed to determine whether the rooster assay is a good proxy for intestinal digestion in ruminants.

In summary, this procedure uses a relatively simple, noninvasive animal protocol to assess individual AA absorption with adequate precision to allow assessment of ingredient values even with relatively small changes in dietary substitution. The downside is the cost of isotope required to conduct the work (US\$350/infusion) and the cost of MS analyses (US\$390-540/infusion). Using 6 observations (infusions) per treatment as herein would yield a cost for assessing an ingredient of approximately US $\$ 4,800$.

\section{Future Work}

Some aspects of the current research can be improved when conducting future trials. An increase in the isotope infusion time should yield better estimates of the slowly exchanging body protein pool. By better defining isotope movement into the slow $\mathrm{T} / \mathrm{O}$ protein pool, the dietary entry rate estimates will more closely reflect true entry rates, although careful animal management allows subtraction of these overestimates as herein. However, improved estimates of the rates of body protein synthesis should allow more robust diet designs and assessment of treatment effects on protein $\mathrm{T} / \mathrm{O}$ to gain a better understanding of the extent of protein $\mathrm{T} / \mathrm{O}$ and its energetic costs. The increased observation time would also reduce variation potentially caused by small changes in eating rates within the 2 -h window used herein. It is unclear how much additional infusion time would be required to achieve more precise determinations of protein $\mathrm{T} / \mathrm{O}$, but 4 to $6 \mathrm{~h}$ of infusion would certainly be an improvement.

Sampling plasma after the isotope infusion has ceased does not provide any additional analytical power if the times match those for the start of the infusion, although it still extends the observational window, which helps ensure that the sampling window is more representative of a daily rate. However, those samples would have more power if they were offset in time relative to cessation of the infusion compared with times after infusions start to achieve more frequent sampling of the transition to plateau. For example, if sampling occurred at $0,15,30$, and 60 min after infusion start, sampling at 7, 22, 37, and 52 min after infusion stop would yield more information than every 15 min after infusion stop. The increased time frequency may add precision by better characterizing the fast and slow $\mathrm{T} / \mathrm{O}$ pools while retaining the longer time window. However, by increasing sampling frequency at the beginning and halting sampling at the end of the infusion, personnel time and time the animal is under intensive investigation are reduced.

Test ingredients should be fed at higher inclusion rates where possible and should be added on top of the $\mathrm{BD}$ rather than substituted for SBM or another ingredient within the BD. This will reduce the independent variables, maintaining orthogonality and helping to ensure unique derivations of AA supplied by each test ingredient. Fixing DMI to be equal among animals and periods may also be helpful in reducing variation and reliance on a term such as RDP, but this would be very difficult to manage.

\section{CONCLUSIONS}

As we originally hypothesized, an isotope-based assessment of AA supply appears to be an accurate and relatively precise in vivo noninvasive method of determining AA plasma entry rates for individual feed ingredients in a normal feeding environment. Additionally, the method generates a plasma AA entry rate, thus providing an absorbed value that can be incorporated directly into postabsorptive models. With some further refinement, this method can be used to create a library of true AA availability values for a variety of feed ingredients, leading to more accurate diet formulation, reduced environmental loading, increased animal efficiency, and increased milk production. More accurate values of AA digestibility and RUP measurements for ingredients will also help determine fair market value for ingredients.

\section{ACKNOWLEDGMENTS}

Funding for K. A. Estes was provided by Balchem Corporation (New Hampton, NY). Funding for the experimental work was provided by a grant from the Poultry Protein and Fat Council of the U.S. Poultry and Egg Association (Tucker, GA), the Virginia Agricultural Experiment Station (Blacksburg), and the 
Hatch Program of the National Institute of Food and Agriculture, U.S. Department of Agriculture (Washington, DC). The blood meal and feather meal used for the project were provided by Papillon (Easton, MD). The critical comments of E. Evans and C. Stoffel are gratefully acknowledged.

\section{REFERENCES}

Ainslie, S. J., D. G. Fox, T. C. Perry, D. J. Ketchen, and M. C. Barry. 1993. Predicting amino acid adequacy of diets fed to Holstein steers. J. Anim. Sci. 71:1312-1319.

Arriola Apelo, S. I., A. L. Bell, K. Estes, J. Ropelewski, M. J. de Veth, and M. D. Hanigan. 2014a. Effects of reduced dietary protein and supplemental rumen-protected essential amino acids on the nitrogen efficiency of dairy cows. J. Dairy Sci. 97:5688-5699.

Arriola Apelo, S. I., J. R. Knapp, and M. D. Hanigan. 2014b. Invited review: Current representation and future trends of predicting amino acid utilization in the lactating dairy cow. J. Dairy Sci. 97:4000-4017.

Borucki Castro, S., H. Lapierre, L. Phillip, P. Jardon, and R. Berthiaume. 2008. Towards non-invasive methods to determine the effect of treatment of soya-bean meal on lysine availability in dairy cows. Animal 2:224-234.

Boucher, S. E., S. Calsamiglia, C. M. Parsons, H. H. Stein, M. D. Stern, P. S. Erickson, P. L. Utterback, and C. G. Schwab. 2009. Intestinal digestibility of amino acids in rumen undegradable protein estimated using a precision-fed cecectomized rooster bioassay: I. Soybean meal and soyplus. J. Dairy Sci. 92:4489-4498.

Calder, A. G., K. E. Garden, S. E. Anderson, and G. E. Lobley. 1999. Quantitation of blood and plasma amino acids using isotope dilution electron impact gas chromatography/mass spectrometry with $\mathrm{u}-(13) \mathrm{c}$ amino acids as internal standards. Rapid Commun. Mass Spectrom. 13:2080-2083.

Calsamiglia, S., and M. D. Stern. 1995. Three-step in vitro procedure for estimating intestinal digestion of protein in ruminants. J. Anim. Sci. 73:1459-1465.

Choung, J.-J., and D. G. Chamberlain. 1995. Effects of abomasal infusions of sodium caseinate and of casein hydrolysates varying in the relative proportions of peptides and free amino acids on milk production in dairy cows. J. Dairy Res. 62:423-429.

Church, D., D. Daugherty, and W. Kennick. 1982. Nutritional evaluation of feather and hair meals as protein sources for ruminants. J. Anim. Sci. 54:337-344.

Cochran, R., D. Adams, J. Wallace, and M. Galyean. 1986. Predicting digestibility of different diets with internal markers: Evaluation of four potential markers. J. Anim. Sci. 63:1476-1483.

Colombini, S., G. A. Broderick, and M. K. Clayton. 2011. Effect of quantifying peptide release on ruminal protein degradation determined using the inhibitor in vitro system. J. Dairy Sci. 94:19671977.

Cunningham, K. D., M. J. Cecava, and T. R. Johnson. 1994. Flows of nitrogen and amino acids in dairy cows fed diets containing supplemental feather meal and blood meal. J. Dairy Sci. 77:3666-3675.

Dhanoa, M. S. 1988. On the analysis of Dacron bag data for low degradability feeds. Grass Forage Sci. 43:441-444.

El-Kadi, S. W., R. L. Baldwin, N. E. Sunny, S. L. Owens, and B. J. Bequette. 2006. Intestinal protein supply alters amino acid, but not glucose, metabolism by the sheep gastrointestinal tract. J. Nutr. 136:1261-1269.

Estes, K. A. 2016. Assessing intestinal absorption of amino acids utilizing an isotope based approach. MS thesis. Virginia Polytechnic Institute and State University, Blacksburg, VA.

Freetly, H. C., J. R. Knapp, C. C. Calvert, and R. L. Baldwin. 1993. Development of a mechanistic model of liver metabolism in the lactating cow. Agric. Syst. 41:157-195.

Garcia, A. R., A. B. Batal, and N. M. Dale. 2007. A comparison of methods to determine amino acid digestibility of feed ingredients for chickens. Poult. Sci. 86:94-101.
Gargallo, S., S. Calsamiglia, and A. Ferret. 2006. Technical note: A modified three-step in vitro procedure to determine intestinal digestion of proteins. J. Anim. Sci. 84:2163-2167.

Goedeken, F. K., T. Klopfenstein, R. Stock, and R. Britton. 1990a. Hydrolyzed feather meal as a protein source for growing calves. J. Anim. Sci. 68:2945-2953.

Goedeken, F. K., T. Klopfenstein, R. Stock, R. Britton, and M. Sindt. 1990b. Protein value of feather meal for ruminants as affected by blood additions. J. Anim. Sci. 68:2936-2944.

Graulet, B., C. Richard, and J. C. Robert. 2005. Methionine availability in plasma of dairy cows supplemented with methionine hydroxy analog isopropyl ester. J. Dairy Sci. 88:3640-3649.

Gutierrez-Botero, M., A. Foskolos, D. A. Ross, and M. E. Van Amburgh. 2014. Balancing for intestinal nitrogen indigestibility in high producing lactating cattle: One step closer to feeding a cow like a pig? Pages 140-147 in Proc. Cornell Nutrition Conference for Feed Manufacturers. Cornell University, East Syracuse, NY.

Hanigan, M., and R. Baldwin. 1994. A mechanistic model of mammary-gland metabolism in the lactating cow. Agric. Syst. 45:369-419.

Hanigan, M. D., L. Crompton, J. Metcalf, and J. France. 2001. Modelling mammary metabolism in the dairy cow to predict milk constituent yield, with emphasis on amino acid metabolism and milk protein production: Model construction. J. Theor. Biol. 213:223239.

Hanigan, M. D., C. Reynolds, D. Humphries, B. Lupoli, and J. Sutton. 2004a. A model of net amino acid absorption and utilization by the portal-drained viscera of the lactating dairy cow. J. Dairy Sci. 87:4247-4268.

Hanigan, M. D., L. A. Crompton, C. K. Reynolds, D. Wray-Cahen, M. A. Lomax, and J. France. 2004b. An integrative model of amino acid metabolism in the liver of the lactating dairy cow. J. Theor. Biol. 228:271-289.

Hanigan, M. D., J. France, S. J. Mabjeesh, W. C. McNabb, and B. J. Bequette. 2009. High rates of mammary tissue protein turnover in lactating goats are energetically costly. J. Nutr. 139:1118-1127.

Harper, A. E. 1965. Effect of variations in protein intake on enzymes of amino acid metabolism. Can. J. Biochem. 43:1589-1603.

Hristov, A. N., W. J. Price, and B. Shafii. 2004. A meta-analysis examining the relationship among dietary factors, dry matter intake, and milk and milk protein yield in dairy cows. J. Dairy Sci. 87:2184-2196.

Hušek, P. 1991. Rapid derivatization and gas chromatographic determination of amino acids. J. Chromatogr. A 552:289-299.

Khezri, A., S. Baker, and A. Khatibi. 2011. Improving the efficiency of dietary nitrogen use in dairy farms to minimize environmental pollution. Pages 731-736 in Proc. 3rd International Conference on Sustainable Animal Agriculture for Developing Countries, Nakhon Ratchasima, Thailand

Kim, E. J., P. L. Utterback, T. J. Applegate, and C. M. Parsons. 2011. Comparison of amino acid digestibility of feedstuffs determined with the precision-fed cecectomized rooster assay and the standardized ileal amino acid digestibility assay. Poult. Sci. 90:2511-2519.

Klemesrud, M. J., T. Klopfenstein, A. Lewis, D. Shain, and D. Herold. 1997. Limiting amino acids in meat and bone and poultry byproduct meals. J. Anim. Sci. 75:3294-3300.

Klemesrud, M. J., T. J. Klopfenstein, and A. Lewis. 1998. Complementary responses between feather meal and poultry by-product meal with or without ruminally protected methionine and lysine in growing calves. J. Anim. Sci. 76:1970-1975.

Klemesrud, M. J., T. J. Klopfenstein, and A. J. Lewis. 2000. Evaluation of feather meal as a source of sulfur amino acids for growing steers. J. Anim. Sci. 78:207-215.

Lapierre, H., G. Holtrop, A. G. Calder, J. Renaud, and G. E. Lobley. 2012. Is D-methionine bioavailable to the dairy cow? J. Dairy Sci. 95:353-362.

MacRae, J. C., L. A. Bruce, D. S. Brown, and A. G. Calder. 1997a. Amino acid use by the gastrointestinal tract of sheep given lucerne forage. Am. J. Physiol. 273:G1200-G1207.

MacRae, J. C., L. A. Bruce, D. S. Brown, D. A. H. Farningham, and M. Franklin. 1997b. Absorption of amino acids from the intestine 
and their net flux across the mesenteric- and portal-drained viscera of lambs. J. Anim. Sci. 75:3307-3314.

Maxin, G., D. R. Ouellet, and H. Lapierre. 2013. Effect of substitution of soybean meal by canola meal or distillers grains in dairy rations on amino acid and glucose availability. J. Dairy Sci. 96:7806-7817.

Noftsger, S., and N. R. St-Pierre. 2003. Supplementation of methionine and selection of highly digestible rumen undegradable protein to improve nitrogen efficiency for milk production. J. Dairy Sci. 86:958-969.

NRC. 2001. Nutrient Requirements of Dairy Cattle. 7th rev. ed. National Academy Press, Washington, DC.

Oltjen, R. R., L. Slyter, and R. Wilson. 1972. Urea levels, protein and diethylstilbestrol for growing steers fed purified diets. J. Nutr. 102:479-488.

Ørskov, E. R., and I. McDonald. 1979. The estimation of protein degradability in the rumen from incubation measurements weighted according to rate of passage. J. Agric. Sci. 92:499-503.

Paz, H. A., T. Klopfenstein, D. Hostetler, S. Fernando, E. CastilloLopez, and P. Kononoff. 2014. Ruminal degradation and intestinal digestibility of protein and amino acids in high-protein feedstuffs commonly used in dairy diets. J. Dairy Sci. 97:6485-6498.

Press, W. H. 2007. Numerical Recipes: The Art of Scientific Computing. 3rd ed. Cambridge University Press, Cambridge, UK.

Ravindran, V., L. Hew, G. Ravindran, and W. Bryden. 1999. A comparison of ileal digesta and excreta analysis for the determination of amino acid digestibility in food ingredients for poultry. Br. Poult. Sci. 40:266-274.

Robinson, P. H., J. G. Fadel, and S. Tamminga. 1986. Evaluation of mathematical models to describe neutral detergent residue in terms of its susceptibility to degradation in the rumen. Anim. Feed Sci. Technol. 15:249-271.

Ross, D. A., M. Gutierrez-Botero, and M. E. Van Amburgh. 2013. Development of an in vitro intestinal digestibility assay for ruminant feeds. Pages 190-202 in Proc. Cornell Nutrition Conference for Feed Manufacturers. Cornell Univ., East Syracuse, NY.

Rutherfurd, S. M., and P. J. Moughan. 1998. The digestible amino acid composition of several milk proteins: Application of a new bioassay. J. Dairy Sci. 81:909-917.
Sessions. 2006. Isotope-ratio detection for gas chromatography. J. Sep. Sci. 21:1946-1961.

Spires, H. R., J. H. Clark, R. G. Derrig, and C. L. Davis. 1975. Milk production and nitrogen utilization in response to postruminal infusion of sodium caseinate in lactating cows. J. Nutr. 105:11111121.

Stern, M. D., A. Bach, and S. Calsamiglia. 1997. Alternative techniques for measuring nutrient digestion in ruminants. J. Anim. Sci. 75:2256-2276.

Titgemeyer, E., N. Merchen, Y. Han, C. Parsons, and D. Baker. 1990. Assessment of intestinal amino acid availability in cattle by use of the precision-fed cecectomized rooster assay. J. Dairy Sci. 73:690693.

Titgemeyer, E. C., N. R. Merchen, and L. L. Berger. 1989. Evaluation of soybean meal, corn gluten meal, blood meal and fish meal as sources of nitrogen and amino acids disappearing from the small intestine of steers. J. Anim. Sci. 67:262-275.

Turner, C. W., and H. A. Herman. 1931. Determination of the blood and plasma volume of dairy cattle. University of Missouri Agricultural Experimental Station Bulletin 159. University of Missouri, Columbia

Waltz, D. M., M. Stern, and D. Illg. 1989. Effect of ruminal protein degradation of blood meal and feather meal on the intestinal amino acid supply to lactating cows. J. Dairy Sci. 72:1509-1518.

White, R. R., Y. Roman-Garcia, J. L. Firkins, M. J. VandeHaar, L. A. Armentano, T. M. McGill, R. L. Garnett, and M. D. Hanigan. 2017. Evaluation of the National Research Council (2001) dairy model and derivation of new prediction equations. 1. Digestibility of fiber, fat, protein, and nonfiber carbohydrate. J. Dairy Sci. 100:3591-3610.

Whitehouse, N., C. Schwab, S. Fredin, and A. Brito. 2016. Determination of relative methionine bioavailability in lactating cows fed Smartamine M, Mepron, and Aminoshure M using the plasma-free AA dose-response method. J. Anim. Sci. 94(Suppl. 5):776-777.

Williams, A. 1978. The amino acid, collagen and mineral composition of preruminant calves. J. Agric. Sci. 90:617-624 